\title{
Article \\ Factors Affecting Alkali Activation of Laterite Acid
Leaching Residues
}

\author{
Konstantinos Komnitsas ${ }^{1, *(1)}$, Georgios Bartzas ${ }^{2}\left(\mathbb{D}\right.$, Vasiliki Karmali ${ }^{1}$ and Evangelos Petrakis ${ }^{1}(\mathbb{D}$ \\ 1 School of Mineral Resources Engineering, Technical University of Crete, 73100 Chania, Greece; \\ vkarmali@isc.tuc.gr (V.K.); vpetraki@mred.tuc.gr (E.P.) \\ 2 School of Mining and Metallurgical Engineering, National Technical University of Athens, \\ 15780 Zografos, Greece; gbartzas@metal.ntua.gr \\ * Correspondence: komni@mred.tuc.gr; Tel.: +30-28210-37686
}

check for updates

Citation: Komnitsas, K.; Bartzas, G.; Karmali, V.; Petrakis, E. Factors Affecting Alkali Activation of Laterite Acid Leaching Residues.

Environments 2021, 8, 4. https://

doi.org/10.3390/environments8010004

Received: 11 December 2020

Accepted: 7 January 2021

Published: 10 January 2021

Publisher's Note: MDPI stays neutral with regard to jurisdictional clai$\mathrm{ms}$ in published maps and institutional affiliations.

Copyright: $\odot 2021$ by the authors. Licensee MDPI, Basel, Switzerland. This article is an open access article distributed under the terms and conditions of the Creative Commons Attribution (CC BY) license (https:// creativecommons.org/licenses/by/ $4.0 /)$.
Abstract: In this experimental study, the alkali activation of acid leaching residues using a mixture of sodium hydroxide $(\mathrm{NaOH})$ and alkaline sodium silicate solution $\left(\mathrm{Na}_{2} \mathrm{SiO}_{3}\right)$ as activators is investigated. The residues were also calcined at 800 and $1000{ }^{\circ} \mathrm{C}$ for $2 \mathrm{~h}$ or mixed with metakaolin (MK) in order to increase their reactivity. The effect of several parameters, namely the $\mathrm{H}_{2} \mathrm{O} / \mathrm{Na}_{2} \mathrm{O}$ and $\mathrm{SiO}_{2} / \mathrm{Na}_{2} \mathrm{O}$ ratios present in the activating solution, the pre-curing time (4-24 h), the curing temperature $\left(40-80^{\circ} \mathrm{C}\right)$, the curing time ( 24 or $48 \mathrm{~h}$ ), and the ageing period (7-28 days) on the properties of the produced alkali activated materials (AAMs), including compressive strength, porosity, water absorption, and density, was explored. Analytical techniques, namely X-ray diffraction (XRD), Fourier transform infrared (FTIR) spectroscopy, scanning electron microscopy (SEM), and elemental mapping analysis were used for the identification of the morphology and structure of the final products. The experimental results show that the laterite acid leaching residues cannot be alkali activated in an unaltered state, and the compressive strength of the produced AAMs barely reaches 1.4 $\mathrm{MPa}$, while the mixing of the residues with $10 \mathrm{wt} \%$ metakaolin results in noticeably higher compressive strength $(41 \mathrm{MPa})$. Moreover, the calcination of residues at 800 and $1000{ }^{\circ} \mathrm{C}$ has practically no beneficial effect on alkali activation. Alkali activated materials produced under the optimum synthesis conditions were subjected to high temperature firing for $2 \mathrm{~h}$ and immersed in distilled water or acidic solution $\left(1 \mathrm{~mol} \mathrm{~L}^{-1} \mathrm{HCl}\right)$ for 7 and 30 days in order to assess their structural integrity under different environmental conditions. This study explores the potential of alkali activation of laterite leaching residues amended with the addition of metakaolin for the production of AAMS that can be used as binders or in several construction applications in order to enable their valorization and also improve the environmental sustainability of the metallurgical sector.

Keywords: alkali activated materials (AAMs); laterite acid leaching residues; metakaolin; compressive strength

\section{Introduction}

Heap leaching is one of the oldest low-cost hydrometallurgical processes that can be used for the extraction of base and precious metals, mainly from low-grade ores and secondary resources [1-4]. The recovery of the metals from the pregnant leach solution (PLS) generated after leaching is mainly accomplished with the use of solvent extraction and electrowinning (SX/EW). Heap leaching can be applied for the treatment of various sulphide and oxide ores, while its efficiency depends on the mineralogical characteristics of the raw materials, the overall design of the process, and the selectivity of the leaching agent [5-9]. One of the major environmental concerns associated with heap leaching is the management of the final leaching residues, the so-called spent ore, which may contain residual metal values and chemicals. The current industrial practice indicates that these residues are mainly disposed/stockpiled on site or leached at later periods for additional metal extraction. However, if residues are not properly managed, e.g., are left 
un-lined or unmonitored, they may cause severe contamination of nearby soils and water resources, especially in regions with favorable climatic conditions (e.g., high precipitation and temperature). So far, only a few studies have been carried out to predict or assess risk in waste disposal areas, while no studies are available for their valorization [10-13].

Laterite ores consist mainly of iron oxides (goethite $(\mathrm{FeO}(\mathrm{OH}))$ and hematite $\left(\mathrm{Fe}_{2} \mathrm{O}_{3}\right)$ ), aluminum oxides $\left(\mathrm{Al}_{2} \mathrm{O}_{3}\right)$, quartz $\left(\mathrm{SiO}_{2}\right)$, kaolinite $\left(\mathrm{Al}_{2} \mathrm{Si}_{2} \mathrm{O}_{5}(\mathrm{OH})_{4}\right)$, nontronite $\left(\mathrm{Na}_{0.3} \mathrm{Fe}_{2}((\mathrm{Si}\right.$, $\left.\mathrm{Al})_{4} \mathrm{O}_{10}(\mathrm{OH})_{2} \cdot \mathrm{nH}_{2} \mathrm{O}\right)$, serpentine $\left((\mathrm{Mg}, \mathrm{Fe}, \mathrm{Ni}, \mathrm{Al}, \mathrm{Zn}, \mathrm{Mn})_{2-3} \cdot(\mathrm{Si}, \mathrm{Al}, \mathrm{Fe})_{2} \mathrm{O}_{5}(\mathrm{OH})_{4}\right)$, and chlorite $\left((\mathrm{Mg}, \mathrm{Fe}, \mathrm{Al})_{6}(\mathrm{Si}, \mathrm{Al})_{4} \mathrm{O}_{10}(\mathrm{OH})_{8}\right)$. They account for more than $70 \%$ of the world's nickel reserves and more than $50 \%$ of total Ni production [14-16]. In Greece, the major laterite deposits are located on the island of Evia and the Lokris region in central Greece, as well as in Kastoria in northwestern Greece [17]. These deposits are classified into two main types, namely limonitic, with high iron and low magnesium content (on Evia and in Lokris), and saprolitic, with high magnesium and low iron content (in Kastoria). Greek laterites have been treated pyrometallurgically for over 50 years for the production of ferronickel (FeNi) at the Larco General Mining \& Metallurgical Co. S.A (LARCO) plant, located in Larymna (central Greece) [18]. Due to the decreasing grade of the Greek laterite ores and the urgent need to reduce environmental impacts, several studies have been carried out over the last 35 years for the development of alternative treatment techniques involving atmospheric [19,20], pressure [21], and heap leaching [22-24]. Geopolymers, inorganic polymers, or alkali activated materials (AAMs) are partially amorphous materials that are produced by chemical reactions between aluminosilicate raw materials, alkaline $(\mathrm{NaOH}$ and $\mathrm{KOH}$ ), and/or silicate solutions. They contain Si-O-Al bonds, while the tetrahedral $\mathrm{AlO}_{4}$ and $\mathrm{SiO}_{4}$ units are built in three dimensional structures [25-29].

Alkali activated materials are partially amorphous and consist of a network of $\mathrm{SiO}_{4}$ and $\mathrm{AlO}_{4}$ tetrahedra, which are linked alternately by sharing all oxygen atoms. Their production requires reactions between aluminosilicate raw materials and concentrated alkaline and silicate solutions, often at ambient temperature. The release of $\mathrm{Si}$ and $\mathrm{Al}$ ions results in the formation of $\mathrm{Mx}\left(\mathrm{AlO}_{2}\right) \mathrm{y}\left(\mathrm{SiO}_{2}\right) \mathrm{z} \cdot \mathrm{nMOH} \cdot \mathrm{mH}_{2} \mathrm{O}$ gel $\left(\mathrm{M}: \mathrm{K}^{+}\right.$or $\left.\mathrm{Na}^{+}\right)$, which hardens within a few hours. The degree of polymerization of silicate species is mainly affected by the alkalinity of the activating solution, the temperature, and the liquid to solid ratio in the starting mixture $[30,31]$. Raw materials and reagents are mixed together in order to optimize the $\mathrm{SiO}_{2}: \mathrm{Al}_{2} \mathrm{O}_{3}$ ratio in the reactive paste and then cast and cured for a few hours at mild temperature so that matrices with the desired microstructure and properties are obtained [32-36]. Several factors affect the efficiency of alkali activation and the production of AAMs with beneficial properties, mainly the $\mathrm{H}_{2} \mathrm{O} / \mathrm{Na}_{2} \mathrm{O}$ and the $\mathrm{SiO}_{2} / \mathrm{Na}_{2} \mathrm{O}$ molar ratios present in the alkali activating solution $[33,36,37]$ and the curing temperature [38-40]. Alkali activation can be used for the valorization of several industrial wastes and the production of end-products with tailored physical and chemical properties, which can be used as building elements or binders, or in several other applications in various sectors [41-46].

So far, several studies have been carried out, mainly by African scientists, in order to investigate the alkali activation potential of lateritic soils, which are often used for the construction of roads and houses in African countries [47,48]. On the other hand, only a few studies pertinent to valorization of leaching residues through alkali activation are available [49]. Thus, the objective of the present study was to explore the alkali activation potential of laterite acid leaching residues in the presence of metakaolin (MK) and develop an integrated approach that will result in their valorization and the production of high added value products that can be used as binders or construction elements, in line with the zero-waste approach and circular economy principles.

\section{Materials and Methods}

\subsection{Materials}

The leaching residues (LR) were obtained after the implementation of laboratory column leaching tests using Greek laterites and $\mathrm{H}_{2} \mathrm{SO}_{4}$ as a leaching medium. The exper- 
imental conditions used are similar to those described in previous recent studies [24,49]. For the production of AAMs, the leaching residues that were used as precursors were first subjected to solid:liquid separation and were then washed to remove any remaining acidity and dried at $80^{\circ} \mathrm{C}$ for 1 day. In addition, in order to study the effect of calcination of the precursors on alkali activation, the LR were calcined at 800 and $1000{ }^{\circ} \mathrm{C}$ for $2 \mathrm{~h}$. In order to regulate the $\mathrm{Si} / \mathrm{Al}$ ratio in the precursors and thus increase their reactivity during alkali activation, metakaolin (MK) was mixed with the residues in different proportions, e.g., 5 and $10 \mathrm{wt} \%$. Metakaolin was obtained after calcination of kaolin $\left(\mathrm{Al}_{2} \mathrm{Si}_{2} \mathrm{O}_{5}(\mathrm{OH})_{4}\right.$, Fluka $)$ at $750{ }^{\circ} \mathrm{C}$ for $2 \mathrm{~h}$ in a laboratory oven (N-8L Selecta, Abrera, Spain). The use of metakaolin is considered beneficial during alkali activation due to its high amorphous content and its pozzolanic nature. Care should be taken during the selection of the kaolin's calcination temperature because, if the temperature is lower than $700{ }^{\circ} \mathrm{C}$, the produced metakaolin contains unreactive kaolin and exhibits low reactivity, while, if the calcination temperature exceeds $850^{\circ} \mathrm{C}$, crystallization occurs and, as a result, lower amorphicity and reactivity are anticipated [50-52].

The chemical composition of the raw materials used, in the form of oxides, and their particle size (expressed as percentage smaller than a specific size) are presented in Table 1. Loss on ignition (LOI) was determined by heating the materials at $1050{ }^{\circ} \mathrm{C}$ for $4 \mathrm{~h}$. Particle size analysis was determined using a laser particle size analyzer (Mastersizer S, Malvern Instruments, Malvern, UK).

Table 1. Chemical composition ( $(\mathrm{w} t \%)$ and particle size distribution of raw materials.

\begin{tabular}{ccc}
\hline Component (wt\%) & Leaching Residues (LR) & Metakaolin (MK) \\
\hline $\mathrm{SiO}_{2}$ & 30.8 & 54.2 \\
$\mathrm{Al}_{2} \mathrm{O}_{3}$ & 2.3 & 40.3 \\
$\mathrm{Cr}_{2} \mathrm{O}_{3}$ & 2.5 & 0.02 \\
$\mathrm{Na}_{2} \mathrm{O}$ & - & 1.3 \\
$\mathrm{Fe}_{2} \mathrm{O}_{3}$ & 50.9 & 0.6 \\
$\mathrm{MgO}$ & 2.1 & 0.3 \\
$\mathrm{NiO}$ & 0.1 & - \\
$\mathrm{K}_{2} \mathrm{O}$ & - & 2.4 \\
$\mathrm{TiO}_{2}$ & 0.6 & 0.4 \\
$\mathrm{CoO}$ & 0.02 & $<0.00097$ \\
$\mathrm{MnO}$ & 0.3 & 0.01 \\
$\mathrm{CaO}$ & 3.7 & 0.1 \\
$\mathrm{P}_{2} \mathrm{O}_{5}$ & - & 0.5 \\
$\mathrm{SO}$ & - & 0.3 \\
$\mathrm{ZnO}_{3}$ & - & $<0.00003$ \\
$\mathrm{LOI}$ & 6.2 & - \\
$\mathrm{Total}^{*}$ & 99.5 & 100.1 \\
\hline Particle Size & $\mu \mathrm{m}$ & $\mu \mathrm{m}$ \\
\hline $\mathrm{d}_{90}$ & 48.2 & 25.5 \\
$\mathrm{~d}_{50}$ & 9.9 & 8.8 \\
\hline${ }^{*}$ LOI: Loss on ignition. & &
\end{tabular}

As seen from this table, the leaching residues mainly consist of $\mathrm{SiO}_{2}$ and $\mathrm{Fe}_{2} \mathrm{O}_{3}$, while their low content in $\mathrm{Al}_{2} \mathrm{O}_{3}(2.7 \mathrm{wt} \%)$ indicates poor potential for successful alkali activation. Thus, the addition of metakaolin with high $\mathrm{SiO}_{2}(54.2 \mathrm{wt} \%)$ and $\mathrm{Al}_{2} \mathrm{O}_{3}(40.3 \mathrm{wt} \%)$ content is anticipated to regulate the $\mathrm{SiO}_{2} / \mathrm{Al}_{2} \mathrm{O}_{3}$ ratio and increase the reactivity of the starting mixture. Table 1 also shows that both raw materials have adequate and compatible size for alkali activation because their $d_{90}$ values are lower than $50 \mu \mathrm{m}$ [43].

\subsection{Synthesis AAMs}

The alkali activating solution used for the synthesis of AAMs consisted of sodium hydroxide $(\mathrm{NaOH})$ and sodium silicate (7.5-8.5 $\mathrm{wt} \% \mathrm{Na}_{2} \mathrm{O}$ and $\left.25.5-28.5 \mathrm{wt} \% \mathrm{SiO}_{2}, \mathrm{Merck}\right)$ solutions. Sodium hydroxide was prepared by dissolving anhydrous pellets of $\mathrm{NaOH}$ 
(Sigma-Aldrich, St. Louis, MO, USA) in distilled water so that solutions with different molarity $\left(6-10 \mathrm{~mol} \mathrm{~L}^{-1}, \mathrm{M}\right)$ were obtained. The alkali activating solution was left overnight prior to use.

The synthesis of AAMs was carried out by continuous mixing of the raw materials and the activating solution for about $10 \mathrm{~min}$ in a laboratory mixer until a homogenous paste was obtained, which was then cast in cubic molds $50 \times 50 \times 50 \mathrm{~mm}^{3}$. The molds were mechanically vibrated for 5 min to eliminate the air voids and then left at room temperature for 4 to $24 \mathrm{~h}$ (pre-curing time) to enable initiation of alkali activating reactions and early solidification of the paste. The sufficiently hardened specimens were removed from the molds, wrapped in plastic bags to avoid fast evaporation of water, and cured at 40,60, and $80^{\circ} \mathrm{C}$ for 24 or $48 \mathrm{~h}$ in a laboratory oven (Jeio Tech ON-02G, Seoul, Korea). After curing, the specimens were allowed to cool at room temperature for a period of 7 and 28 days. The AAM codes of all tests carried out, the mixing proportions, and the different $\mathrm{H}_{2} \mathrm{O} / \mathrm{Na}_{2} \mathrm{O}$ and $\mathrm{SiO}_{2} / \mathrm{Na}_{2} \mathrm{O}$ ratios in the activating solution are given in Table 2.

Table 2. Alkali activated material (AAM) codes, raw material used, and selected molar ratios in the activating solution.

\begin{tabular}{|c|c|c|c|c|c|c|c|c|}
\hline AAM Code & $\begin{array}{l}\text { Solids } \\
\text { (wt \%) }\end{array}$ & $\begin{array}{c}\mathrm{NaOH} \\
(\mathrm{M})\end{array}$ & $\begin{array}{c}\mathrm{NaOH} \\
(w \mathrm{t} \%)\end{array}$ & $\begin{array}{c}\mathrm{H}_{2} \mathrm{O} \\
(\mathrm{wt} \%)\end{array}$ & $\begin{array}{c}\mathrm{Na}_{2} \mathrm{SiO}_{3} \\
(\mathrm{wt} \%)\end{array}$ & L/S Ratio * & $\mathrm{H}_{2} \mathrm{O} / \mathrm{Na}_{2} \mathrm{O} * *$ & $\mathrm{SiO}_{2} / \mathrm{Na}_{2} \mathrm{O} * *$ \\
\hline LR1 & 78.1 & 6 & 2.2 & 8.8 & 10.9 & 0.25 & 21.2 & 1 \\
\hline LR2 & 75.6 & 8 & 3.1 & 9.1 & 12.2 & 0.27 & 17.4 & 1 \\
\hline LR3 & 73.4 & 10 & 4.0 & 9.3 & 13.3 & 0.29 & 14.8 & 1 \\
\hline MK & 52.0 & 8 & 6.0 & 18.0 & 24.0 & 0.92 & 17.4 & 1 \\
\hline $\begin{array}{c}\text { 800LR } \\
\text { 1000LR }\end{array}$ & 76.0 & 8 & 3.0 & 8.9 & 12.0 & 0.26 & 17.4 & 1 \\
\hline $\begin{array}{c}\text { LR95MK5 } \\
\text { 800LR95MK5 } \\
\text { 1000LR95M5 } \\
\text { LR90MK10 }\end{array}$ & 74.6 & 8 & 3.2 & 9.5 & 12.7 & 0.29 & 17.4 & 1 \\
\hline $\begin{array}{l}\text { 800LR90MK10 } \\
\text { 1000LR90MK10 }\end{array}$ & 75.8 & 8 & 3.1 & 9.0 & 12.1 & 0.27 & 17.4 & 1 \\
\hline LR90MK10-1 & 82.7 & & 3.5 & 10.4 & 3.4 & 0.16 & 14.8 & 0.3 \\
\hline LR90MK10-2 & 80.8 & 8 & 3.4 & 10.2 & 5.6 & 0.19 & 14.8 & 0.5 \\
\hline LR90MK10-3 & 75.0 & & 2.0 & 7.0 & 16.0 & 0.30 & 21.2 & 1.6 \\
\hline
\end{tabular}

${ }^{*}$ Liquid-to-solid ratio in the starting mixture, ${ }^{* *}$ Molar ratios in the activating solution. LR1: AAMs produced from laterite leaching residues using $6 \mathrm{~mol} \mathrm{~L}^{-1} \mathrm{NaOH}$. 800LR: AAMs produced from calcined at $80{ }^{\circ} \mathrm{C}$ laterite leaching residues. LR95MK5: AAMs produced from laterite leaching residues and metakaolin using mass ratio 95:5. LR90MK10-1: AAMs produced from laterite leaching residues and metakaolin using mass ratio $90: 10$ and $\mathrm{SiO}_{2} / \mathrm{Na}_{2} \mathrm{O}$ molar ratio 0.3.

For all specimens, the determined properties were compressive strength (MPa), porosity $(\%)$, water absorption $(\%)$, and density $\left(\mathrm{g} \mathrm{cm}^{-3}\right)$. The durability of the selected AAMs was evaluated after firing them at $200,400,600$, and $800{ }^{\circ} \mathrm{C}$ for $2 \mathrm{~h}$ in a laboratory furnace (N-8L Selecta) as well as after immersion in distilled water or $1 \mathrm{~mol} \mathrm{~L}^{-1} \mathrm{HCl}$ solution for 7 and 30 days.

All tests were carried out in triplicate, and the values given for each parameter are average; it is mentioned that the difference in measurements was marginal and did not exceed $\pm 3.8 \%$.

\subsection{Characterization of Raw Materials and the Produced AAMs}

The laterite leaching residues were first pulverized using a Bico type pulverizer (Type UA, Fritsch, Dresden, Germany). Prior to alkali activation, their reactivity of raw materials was assessed through the leaching of $1.0 \mathrm{~g}$ of each raw material with $100 \mathrm{~mL}$ of $8 \mathrm{~mol} \mathrm{~L}^{-1}(\mathrm{M}) \mathrm{NaOH}$ solution for $24 \mathrm{~h}$ at room temperature $\left(\sim 20{ }^{\circ} \mathrm{C}\right)$ in $250 \mathrm{~mL}$ conical flasks under continuous stirring. After solid and liquid separation with the use of $0.45 \mu \mathrm{m}$ pore size membrane filters (PTFE, Chromafil), the Al and Si concentration in the eluate was determined using an Inductively Coupled Plasma Mass Spectrometry (ICP MS, Agilent 7500cx) equipped with an Agilent ASX-500 Autosampler (Agilent, Santa Clara, CA, USA). 
The chemical composition of the raw materials and the produced AAMs was determined using a Bruker S2 Ranger-energy dispersive $X$-ray fluorescence spectrometer (ED-XRF, Bruker, Karlsruhe, Germany), while their mineralogical analysis using an X-ray diffractometer (Bruker AXS, D8-Advance, Bruker, Karlsruhe, Germany) with a Cu tube and a scanning range from $4^{\circ}$ to $70^{\circ}$ theta $(\theta)$ and a step of $0.02^{\circ}$, and $0.2 \mathrm{~s} /$ step measuring time. The crystalline phases present in the raw materials and the produced specimens were identified with the use of the DiffracPlus Software (EVA v. 2006, Bruker, Karlsruhe, Germany) and the PDF database. Fourier transform infrared (FTIR) analysis was carried out using pellets produced by mixing the pulverized raw material or AAM with $\mathrm{KBr}$ at a ratio of 1:100 w/w. The analysis was carried out at atmospheric pressure under nitrogen atmosphere, with a flow rate of $100 \mathrm{~mL} \mathrm{~min}{ }^{-1}$ and heating rate of $10{ }^{\circ} \mathrm{C} \mathrm{min}{ }^{-1}$ using a PerkinElmer 1000 spectrometer (PerkinElmer, Akron, OH, USA), in the spectra range of 400 to $4000 \mathrm{~cm}^{-1}$. Microstructural analysis of the produced AAMs was performed with the use of scanning electron microscopy (SEM) and energy dispersive $\mathrm{X}$-ray spectroscopy (EDS). For that purpose, a JEOL-6380LV scanning microscope (JEOL Ltd., Tokyo, Japan), operating at an accelerating voltage of $20 \mathrm{kV}$ equipped with an Oxford INCA EDS microanalysis system (Oxford Instruments, Abingdon, UK), was used.

The Brunauer-Emmett-Teller (BET) nitrogen adsorption method (using a Quantachrome Nova 2200 analyser (Anton Paar QuantaTec Inc., Boynton Beach, FL, USA) was considered for the determination of the specific surface area of the raw materials. The compressive strength of the produced AAMs was determined with the use of a MATEST C123N load frame (compression and flexural machine, Matest S.p.A, Treviolo, Bergamo, Italy) with dual range $500 / 15 \mathrm{kN}$. Finally, the apparent density $\left(\mathrm{g} \mathrm{cm}^{-3}\right)$, the porosity (\%), and the water absorption (\%) of the selected AAMs were determined according to the BS EN 1936 standard; 3 measurements using specimens $50 \pm 5 \mathrm{~mm} \times 50 \pm 5 \mathrm{~mm} \times 50 \pm 5 \mathrm{~mm}$ were taken, and average values are given in the paper [53].

\section{Results}

\subsection{Reactivity of Raw Materials}

So far, most studies carried out to assess the reactivity and subsequently the potential of various raw materials (i.e., virgin materials, by-products, and wastes) for alkali activation focused on the calculation of $\mathrm{SiO}_{2} / \mathrm{Al}_{2} \mathrm{O}_{3}$ molar ratios in the raw materials (precursors) [54-58]. However, this ratio provides only an indication of the reactivity rather than defines the actual dissolution of the Si and $\mathrm{Al}$ that participate during alkali activation in the formation of Si-O-Al bonds [59-63]. The concentration of $\mathrm{Al}$ and $\mathrm{Si}$ (in $\mathrm{mg} \mathrm{L}^{-1}$ ) in the eluate after alkaline leaching, using $8 \mathrm{~mol} \mathrm{~L}^{-1} \mathrm{NaOH}$ solution, indicates the reactivity of the raw materials used in the present study (Table 3); in the same Table, the Si/Al molar ratio in the eluate is also provided.

Table 3. Concentration of $\mathrm{Si}, \mathrm{Al}$, and $\mathrm{Si} / \mathrm{Al}$ molar ratios in the eluate.

\begin{tabular}{cccc}
\hline Raw Material & $\begin{array}{c}\mathbf{S i} \\
\mathbf{( m g ~ L}^{-\mathbf{1}} \mathbf{)}\end{array}$ & $\begin{array}{c}\mathbf{A l} \\
\left.\mathbf{( m g ~ L}^{-\mathbf{1}}\right)\end{array}$ & $\begin{array}{c}\text { Si/Al } \\
\text { (Molar Ratio) }\end{array}$ \\
\hline $\begin{array}{c}\text { Leaching residue } \\
\text { Leaching residue calcined at } 800^{\circ} \mathrm{C}\end{array}$ & $20.1 \pm 1.7$ & $2.4 \pm 0.4$ & $8.4 \pm 2.2$ \\
Leaching residue calcined at $1000^{\circ} \mathrm{C}$ & $2.0 \pm 0.9$ & $0.6 \pm 0.1$ & $21.5 \pm 5.1$ \\
Metakaolin & $58.7 \pm 3.2$ & $0.4 \pm 0.1$ & $5.4 \pm 2.0$ \\
\hline
\end{tabular}

It is observed from this data that, after alkaline leaching of laterite residues, the concentrations of $\mathrm{Si}$ and $\mathrm{Al}$ in the eluate were 20.1 and $2.4 \mathrm{mg} \mathrm{L}^{-1}$, respectively. Calcination of laterite residues at $800{ }^{\circ} \mathrm{C}$ significantly reduced the concentration of $\mathrm{Si}$ and $\mathrm{Al}$ in the eluate to 12.9 and $0.6 \mathrm{mg} \mathrm{L}^{-1}$, respectively, while the increase of the calcination temperature to $1000^{\circ} \mathrm{C}$ resulted in a much lower concentration of both elements in the eluate. Previous studies have shown that, after calcination of laterite at temperature higher than $800{ }^{\circ} \mathrm{C}$, structural modifications occur, mainly due to the formation of spinels $\left(\mathrm{Si}_{3} \mathrm{Al}_{4} \mathrm{O}_{12}\right)[64,65]$. 
On the other hand, metakaolin exhibits much higher reactivity, as also indicated in earlier studies [66-68]. In our case, the concentration of Si and Al in the eluate after alkaline leaching of metakaolin was 58.7 and $41.9 \mathrm{mg} \mathrm{L}^{-1}$, respectively, values that indicate high reactivity during alkali activation and provision of sufficient $\mathrm{Si}$ and $\mathrm{Al}$ ions that can participate in the formation of aluminosilicate bonds.

\subsection{Properties of $A A M s$}

\subsubsection{Alkali Activation of Laterite Leaching Residues}

Figure 1 shows the compressive strength of laterite residue based AAMs as a function of curing temperature $\left(40,60\right.$, and $80^{\circ} \mathrm{C}$ ) in relation to the $\mathrm{H}_{2} \mathrm{O} / \mathrm{Na}_{2} \mathrm{O}$ molar ratios (21.2 for LR1, 17.4 for LR2, and 14.8 for LR3) in the activating solution. The difference in $\mathrm{H}_{2} \mathrm{O} / \mathrm{Na}_{2} \mathrm{O}$ molar ratios is due to the slightly different $\mathrm{S} / \mathrm{L}$ ratios used in each case to obtain a paste with optimum flowability. In all tests, the curing and ageing periods were $24 \mathrm{~h}$ and 7 days, respectively, while the $\mathrm{SiO}_{2} / \mathrm{Na}_{2} \mathrm{O}$ molar ratio in the activating solution was kept constant at 1 . It can be seen from this figure that the effect of temperature is important for all $\mathrm{H}_{2} \mathrm{O} / \mathrm{Na}_{2} \mathrm{O}$ molar ratios tested, but the maximum compressive strength recorded is only 1.4 $\mathrm{MPa}$ for LR2 (curing temperature, $80{ }^{\circ} \mathrm{C}$, and $\mathrm{H}_{2} \mathrm{O} / \mathrm{Na}_{2} \mathrm{O}$ molar ratio in the activating solution, 17.4). It is therefore evident that the laterite leaching residues cannot be effectively alkali activated in an unaltered state, mainly due to their low content of $\mathrm{Al}_{2} \mathrm{O}_{3}(2.7 \mathrm{wt} \%$.), as shown in Table 1 . As a result of this, the concentration of $\mathrm{Al}$ ions in the alkaline solution is low and, thus, the $\mathrm{Si} / \mathrm{Al}$ molar ratio in the produced paste is unfavorable for alkaliactivation (Table 3). It is also important to note that the increase of the ageing period from 7 to 28 days has only a marginal beneficial effect on the compressive strength of the produced specimens, which increases slightly to $1.7 \mathrm{MPa}$ (data not shown).

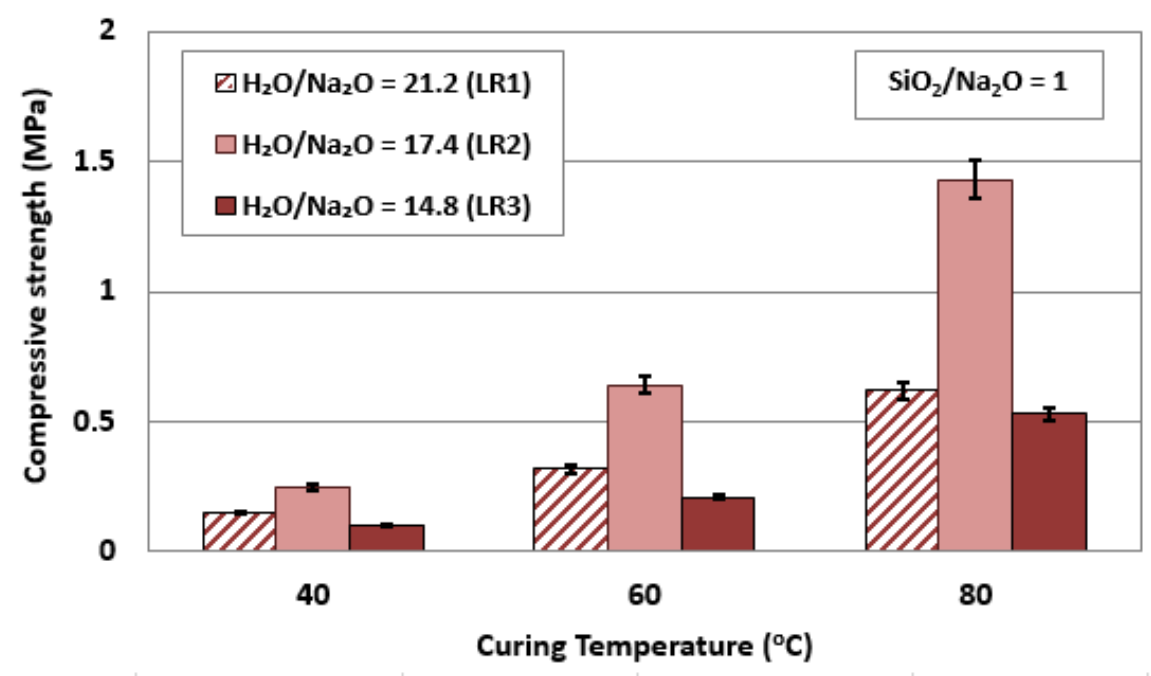

Figure 1. Effect of curing temperature in relation to $\mathrm{H}_{2} \mathrm{O} / \mathrm{Na}_{2} \mathrm{O}$ molar ratios in the activating solution on the compressive strength of laterite based AAMs (pre-curing time, $4 \mathrm{~h}$; curing time, $24 \mathrm{~h}$; ageing period, 7 days; error bars denote standard deviation of measurements obtained from three specimens).

\subsubsection{Effect of the Addition of Metakaolin-Calcination of Leaching Residues}

Figure 2 shows the effect of the addition of metakaolin in the starting mixture as well as th effect of the calcination of leaching residues on the compressive strength of the produced AAMs. It is seen from this data that the compressive strength of the LR95MK5 specimen, for which the metakaolin addition in the staring mixture was only $5 \mathrm{wt} \%$, increased from $1.4 \mathrm{MPa}$ to $12 \mathrm{MPa}$. When the metakaolin addition increased to $10 \mathrm{wt} \%$ (LR90MK10 specimen), a much higher compressive strength value was recorded, i.e., $41 \mathrm{MPa}$. This is due to the high alkali activation potential of metakaolin for which the compressive strength of the respective AAM (MK specimen) reached $55 \mathrm{MPa}$. The beneficial effect of the addition of metakaolin on the compressive strength of the produced AAMs was anticipated by 
taking into consideration its chemical analysis, as shown in Table $1\left(\mathrm{SiO}_{2}, 54.2 \mathrm{wt} \% ; \mathrm{Al}_{2} \mathrm{O}_{3}\right.$, $40.3 \mathrm{wt} \%$ ) as well as the concentration of $\mathrm{Si}$ and $\mathrm{Al}$ in the eluate produced after its alkaline leaching, as shown in Table $3\left(58.7 \mathrm{mg} \mathrm{L}^{-1} \mathrm{Si}\right.$ and $41.9 \mathrm{mg} \mathrm{L}^{-1} \mathrm{Al}$, respectively).

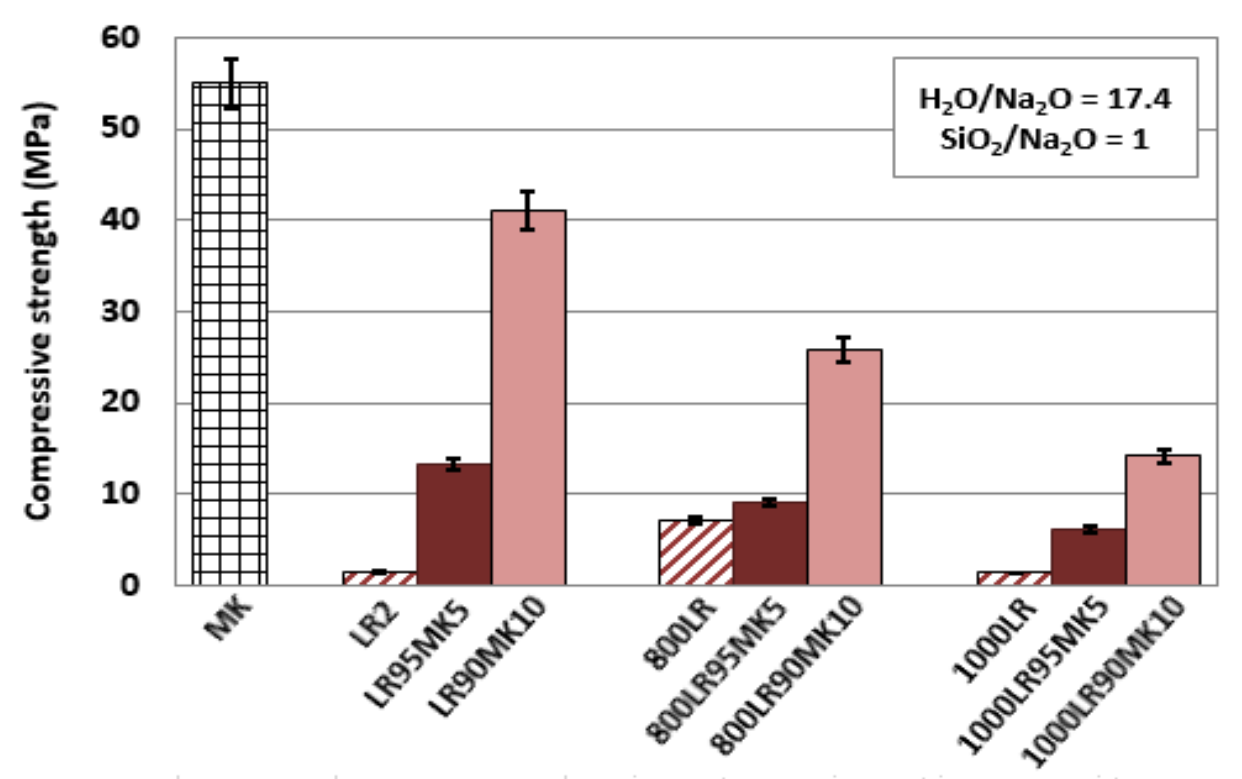

Figure 2. Effect of calcination temperature and addition of MK ( $5 w t \%$ and $10 w t \%)$ to LR on the compressive strength of the produced AAMs (pre-curing time, $4 \mathrm{~h}$; curing temperature, $80^{\circ} \mathrm{C}$; curing period, $24 \mathrm{~h}$; ageing period, 7 days; error bars denote standard deviation of measurements obtained from three specimens).

Another issue that has to be underlined is that both laterite residues and metakaolin had similar grain size, as shown in Table 1 , a factor that is considered beneficial during alkali activation. The specific surface area of laterite leaching residues was $2.1 \mathrm{~m}^{2} / \mathrm{g}$, while that of metakaolin was $2.4 \mathrm{~m}^{2} / \mathrm{g}$, similar to the value determined in another recent study [68]. On the other hand, it is seen that calcination of the laterite leaching residues has a detrimental effect on the compressive strength of the produced specimens. This is mainly due to the decreased dissolution of $\mathrm{Si}$ and $\mathrm{Al}$ ions from the calcined residues (Table 2), which does not enable efficient alkali activation and production of a matrix with beneficial properties. It is mentioned that the specific surface area of calcined laterite leaching residues increased to $15 \mathrm{~m}^{2} / \mathrm{g}$, but its reactivity was not increased due to the occurred phase transformations; it is also noted that materials with high surface areas often require more water during alkali activation and, thus, higher liquid to solid ratios need to be used to obtain a paste with beneficial properties. The only specimens (800LR90MK10 and 1000LR90MK10) that retained a good to moderate compressive strength were the ones produced after alkali activation of mixtures containing $90 \mathrm{wt} \%$ laterite residues calcined at $800{ }^{\circ} \mathrm{C}$ or $1000{ }^{\circ} \mathrm{C}$ and $10 \mathrm{wt} \%$ metakaolin; the respective compressive strength values recorded were 26 and $13 \mathrm{MPa}$.

\subsubsection{Effect of $\mathrm{SiO}_{2} / \mathrm{Na}_{2} \mathrm{O}$ and $\mathrm{H}_{2} \mathrm{O} / \mathrm{Na}_{2} \mathrm{O}$ Molar Ratios in the Activating Solution}

The effect of $\mathrm{SiO}_{2} / \mathrm{Na}_{2} \mathrm{O}$ molar ratio in relation to the corresponding $\mathrm{H}_{2} \mathrm{O} / \mathrm{Na}_{2} \mathrm{O}$ molar ratios in the alkali activating solution on the compressive strength of LR90MK10 AAM are shown in Figure 3. The $\mathrm{H}_{2} \mathrm{O} / \mathrm{Na}_{2} \mathrm{O}$ ratios shown in this figure are the optimum ones for each case examined. The use of a starting mixture containing $90 \mathrm{wt} \%$ laterite leaching residue and $10 \mathrm{wt} \%$ metakaolin was selected because the respective AAM acquired the highest compressive strength (41 MPa), as shown in Figure 2. 


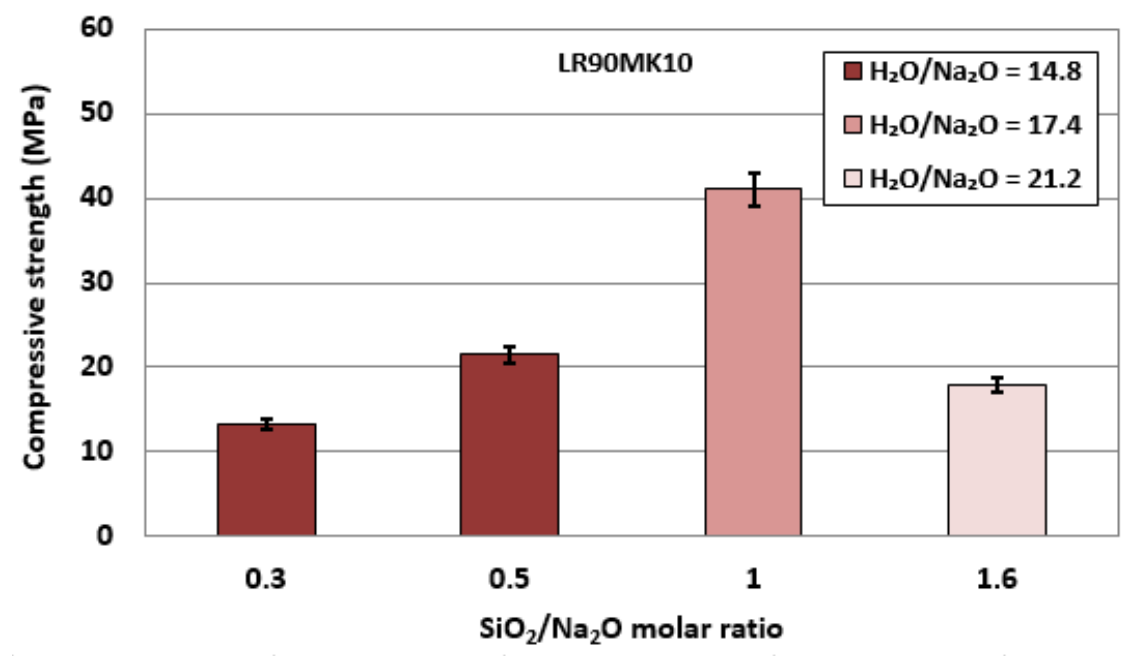

Figure 3. Effect of $\mathrm{SiO}_{2} / \mathrm{Na}_{2} \mathrm{O}$ molar ratios in relation to the corresponding $\mathrm{H}_{2} \mathrm{O} / \mathrm{Na}_{2} \mathrm{O}$ molar ratios in the activating solution on the compressive strength of LR90MK10 AAMs (pre-curing time, $4 \mathrm{~h}$; curing temperature, $80^{\circ} \mathrm{C}$; curing period, $24 \mathrm{~h}$; ageing period, 7 days; error bars denote standard deviation of measurements obtained from three specimens).

The results indicate that the maximum compressive strength (41 MPa) was obtained for a $\mathrm{SiO}_{2} / \mathrm{Na}_{2} \mathrm{O}$ molar ratio equal to 1.0. Higher or lower $\mathrm{SiO}_{2} / \mathrm{Na}_{2} \mathrm{O}$ molar ratios resulted in the production of specimens with lower strength, which did not exceed $21 \mathrm{MPa}$, a value $50 \%$ lower compared to the maximum one obtained. This may be explained by the presence of deficient or excessive alkalinity in the reactive paste, which affects the formation of aluminosilicate bonds and, thus, the microstructure and the strength of the produced specimens. Optimum alkalinity in the reactive paste results in the formation of sufficient $\mathrm{Si}(\mathrm{OH})_{4}$ and $\mathrm{Al}(\mathrm{OH})_{4}$ oligomers and enables polycondensation, which improves the strength of the produced specimens. On the other hand, lower alkalinity, expressed by high $\mathrm{SiO}_{2} / \mathrm{Na}_{2} \mathrm{O}$ molar ratios, slows down the rate of alkali activation reactions while very high alkalinity, expressed by lower $\mathrm{SiO}_{2} / \mathrm{Na}_{2} \mathrm{O}$ molar ratios, results in early precipitation of aluminosilicate gel and increased viscosity of the paste.

The trend shown in the evolution of the compressive strength vs. the $\mathrm{SiO}_{2} / \mathrm{Na}_{2} \mathrm{O}$ molar ratio in this study is very similar to the trend shown in an earlier study investigating the effect of the $\mathrm{SiO}_{2} / \mathrm{K}_{2} \mathrm{O}$ molar ratio on the performance of metakaolin based geopolymers [69].

\subsubsection{Effect of Pre-Curing and Curing Time}

Figure $4 \mathrm{a}, \mathrm{b}$ shows the effect of pre-curing ( 4 to $24 \mathrm{~h}$ ) and curing time ( 24 to $48 \mathrm{~h}$ ) on the compressive strength of LR90MK10 AAM, respectively.

It is seen from these results that the compressive strength decreases with increasing pre-curing and curing time. The maximum value obtained was $41 \mathrm{MPa}$ after a pre-curing period of $4 \mathrm{~h}$ and a curing period of $24 \mathrm{~h}$. The duration of the pre-curing period of the paste defines the extent to which alkali activation reactions proceed so that bonds are developed and specimens acquire sufficient early strength. Longer pre-curing periods may cause higher evaporation of water, which in turn results in incomplete reactions, development of internal stresses, and voids, which hinder the development of high strength during curing. Similar issues are anticipated after prolonged curing periods. It is mentioned that optimum pre-curing and curing periods, which play a major role in the properties of the produced AAMs, depend on the characteristics of the precursors, the S/L ratio during mixing, and the curing temperature, need to be carefully defined during alkali activation [36,70-73]. 


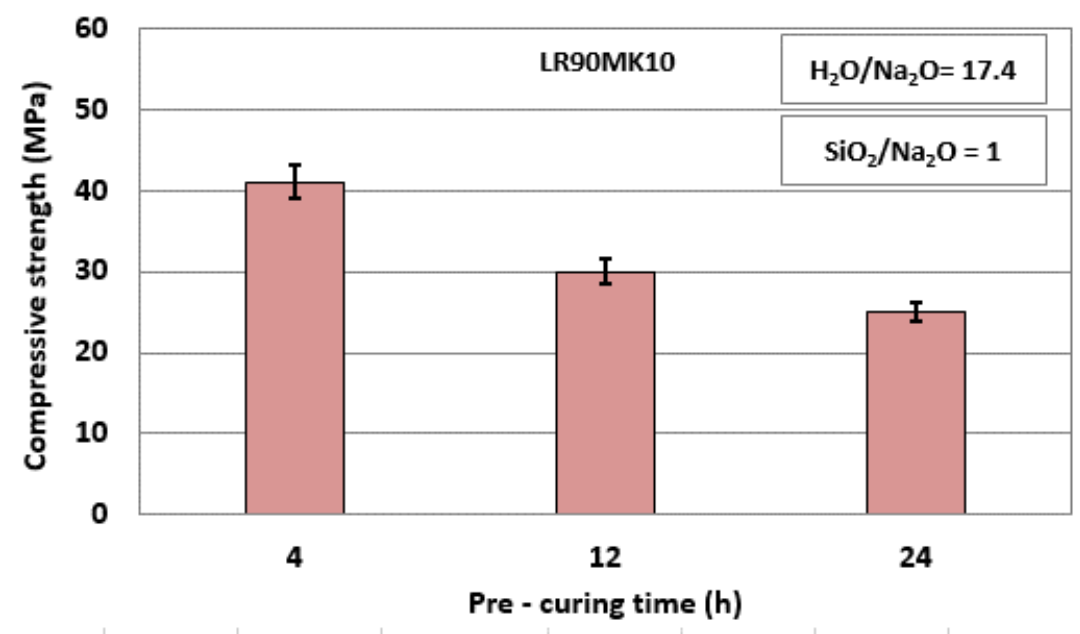

(a)

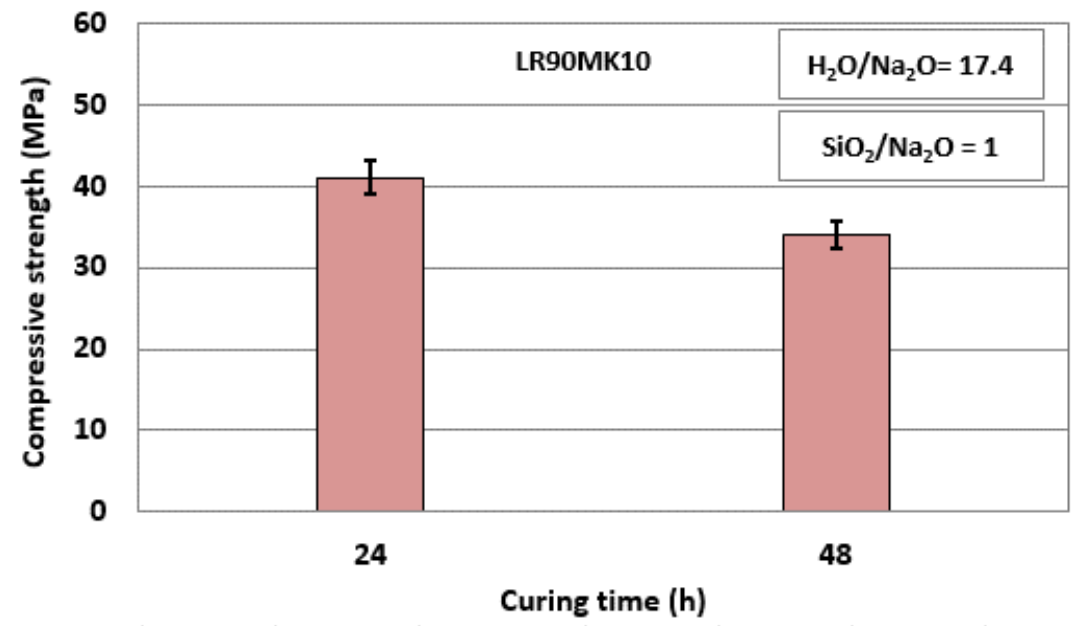

(b)

Figure 4. Effect of (a) pre-curing time and (b) curing time on the compressive strength of LR90MK10 AAM (curing temperature, $80{ }^{\circ} \mathrm{C}$; ageing period, 7 days; error bars denote standard deviation of measurements obtained from three specimens).

\subsubsection{Porosity, Water Absorption, and Apparent Density of Selected AMMs}

Table 4 shows the porosity (\%), water absorption (\%), and apparent density $\left(\mathrm{g} \mathrm{cm}^{-3}\right)$ of the selected AMMs, i.e., LR2, LR95MK5, and LR90MK10; the compressive strength values are also given. It can be observed from this data that the LR90MK10 specimen, which acquires the maximum compressive strength ( $41 \mathrm{MPa})$, has the lowest porosity $(21.3 \%)$ and water absorption $(5.1 \%)$, while its apparent density $\left(2.3 \mathrm{~g} \mathrm{~cm}^{-3}\right)$ is almost identical to the one obtained by LR95MK5. The LR2 specimen, produced by alkali activation of laterite residues using a $\mathrm{H}_{2} \mathrm{O} / \mathrm{Na}_{2} \mathrm{O}$ molar ratio in the 17.4activating solution is characterized by the highest porosity $(36.8 \%)$ and water adsorption (30.7\%) and the lowest apparent density $\left(1.8 \mathrm{~g} \mathrm{~cm}^{-3}\right)$. These values are anticipated by considering the poor alkali activation potential of leaching residues and the very low compressive strength acquired by the respective AAM. 
Table 4. Porosity, water absorption, and apparent density of selected AAMs.

\begin{tabular}{ccccc}
\hline AAM Code & $\begin{array}{c}\text { Compressive Strength } \\
(\mathbf{M P a})\end{array}$ & $\begin{array}{c}\text { Porosity } \\
\mathbf{( \% )}\end{array}$ & $\begin{array}{c}\text { Water Absorption } \\
\mathbf{( \% )}\end{array}$ & $\begin{array}{c}\text { Apparent Density } \\
(\mathbf{g ~ c m}\end{array}$ \\
\hline LR2 & 1.43 & 36.8 & 30.7 & 1.8 \\
LR95MK5 & 13.3 & 27.9 & 13.1 & 2.2 \\
LR90MK10 & 41.0 & 21.3 & 5.1 & 2.3 \\
\hline
\end{tabular}

${ }^{*}$ Curing temperature, $80^{\circ} \mathrm{C}$; curing time, $24 \mathrm{~h}$; ageing period, 7 days.

\subsubsection{Structural Integrity of LR90MK10 AAM}

The structural integrity of LR90MK10 AAMs was assessed after firing for a period of $2 \mathrm{~h}$ at a broad temperature range varying between 200 and $800^{\circ} \mathrm{C}$ and after immersion in distilled water and acidic solution $\left(1 \mathrm{~mol} \mathrm{~L}^{-1} \mathrm{HCl}\right)$ for 7 and 30 days. All AAMs tested were produced under the optimal conditions, i.e., $\mathrm{H}_{2} \mathrm{O} / \mathrm{Na}_{2} \mathrm{O}$ molar ratio, 17.4; curing temperature, $80^{\circ} \mathrm{C}$; and ageing period, 7 days.

Figure 5 presents the evolution of the compressive strength of LR90MK10 AAMs after firing. The compressive strength of the control specimen, which was not subjected to firing, is also shown for comparison. It is seen from this data that the compressive strength decreases gradually with the increase of firing temperature and finally drops to $23.1 \mathrm{MPa}$ at $800{ }^{\circ} \mathrm{C}$, which is considered sufficient for the use of these AAMs as fire resistant materials. It is mentioned for comparison that thermal-stressing (from ambient temperature to $1000{ }^{\circ} \mathrm{C}$ ) results in a reduction of the unconfined compressive strength (UCS) of high-strength concrete by $96 \%$, from about $110 \mathrm{MPa}$ to about $5 \mathrm{MPa}$ [74].

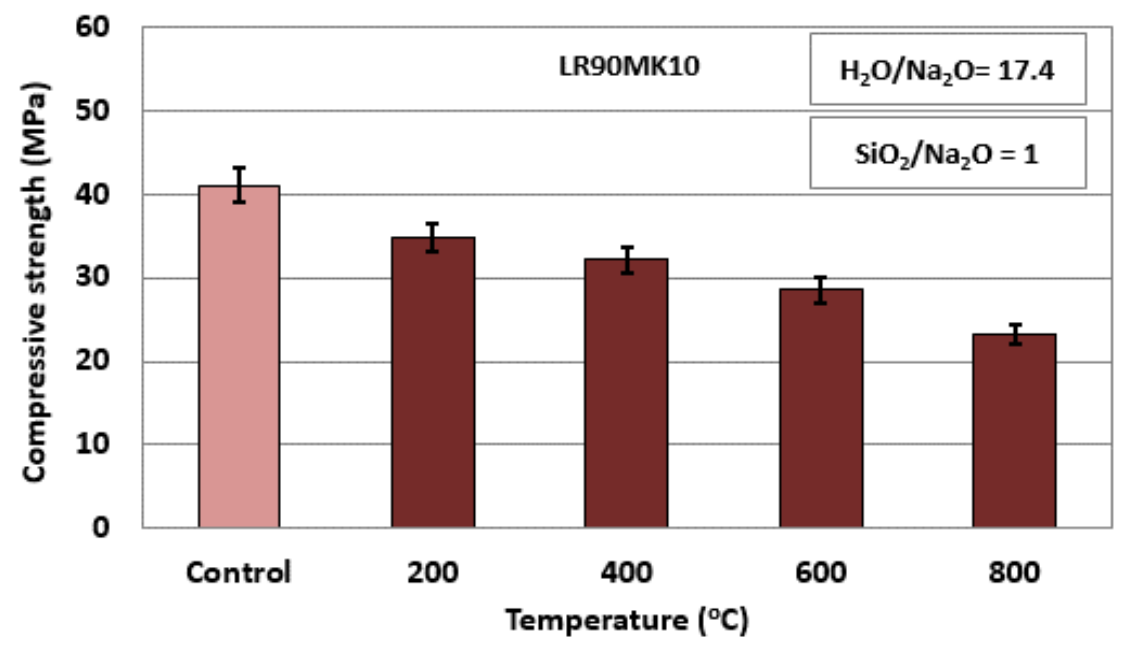

Figure 5. Evolution of the compressive strength of LR90MK10 AAMs after firing between 200 and $800{ }^{\circ} \mathrm{C}$ for $2 \mathrm{~h}$ (pre-curing time, $4 \mathrm{~h}$; curing time, $24 \mathrm{~h}$; curing temperature, $80^{\circ} \mathrm{C}$; ageing period, 7 days; error bars indicate the standard deviation of measurements obtained from three specimens.

Table 5 presents the evolution of weight loss (\%), volumetric shrinkage (\%), porosity $(\%)$, water absorption (\%), and apparent density $\left(\mathrm{g} \mathrm{cm}^{-3}\right)$ of the fired AAMs. It is seen from this data that the specimens after firing at $800{ }^{\circ} \mathrm{C}$ acquire the lowest compressive strength (23.1 MPa) and apparent density $\left(1.8 \mathrm{~g} \mathrm{~cm}^{-3}\right)$, and on the other hand the highest weight loss $(12.1 \%)$, shrinkage $(7.5 \%)$, porosity $(27.2 \%)$, and water adsorption $(14.8 \%)$. As Duxson et al. [75] mention, the increase of shrinkage takes place stepwise in four temperature regions: in Region I, at temperatures below $100{ }^{\circ} \mathrm{C}$, which is attributed to the release of free water; at Region II, between $100-250{ }^{\circ} \mathrm{C}$, due to pore water released from the formed gel; at Region III, between $250-600^{\circ} \mathrm{C}$, due to the loss of bound hydroxyls; and at Region IV, at temperatures higher than $700{ }^{\circ} \mathrm{C}$ due to a viscous sintering-like process. As a result of these processes, the specimens also acquire the lowest density. 
Table 5. Selected properties of LR90MK10 AAMs after firing at high temperatures.

\begin{tabular}{|c|c|c|c|c|c|c|}
\hline $\begin{array}{c}\text { Temperature } \\
\left({ }^{\circ} \mathrm{C}\right)\end{array}$ & $\begin{array}{c}\text { Compressive } \\
\text { Strength (MPa) }\end{array}$ & $\begin{array}{l}\text { Weight } \\
\text { Loss }(\%)\end{array}$ & Shrinkage (\%) & $\begin{array}{l}\text { Apparent Density } \\
\left(\mathrm{g} \mathrm{cm}^{-3}\right)\end{array}$ & Porosity (\%) & $\begin{array}{c}\text { Water } \\
\text { Absorption (\%) }\end{array}$ \\
\hline Control AAM & 41.0 & - & - & 2.3 & 21.3 & 5.1 \\
\hline 200 & 34.8 & 6.3 & 3.2 & 2.0 & 24.8 & 8.2 \\
\hline 400 & 32.1 & 7.6 & 4.3 & 2.1 & 25.1 & 10.8 \\
\hline 600 & 28.5 & 11.2 & 7.3 & 1.8 & 25.0 & 11.3 \\
\hline 800 & 23.1 & 12.1 & 7.5 & 1.8 & 27.2 & 14.8 \\
\hline
\end{tabular}

Figure 6 shows the compressive strength of LR90MK10 AAMs after immersion in distilled water or acidic solution $\left(1 \mathrm{~mol} \mathrm{~L}^{-1} \mathrm{HCl}\right)$ for 7 and 30 days. The compressive strength of the control specimen is also provided for comparison. As seen from this data, the compressive strength of the specimens drops slightly to $37.5 \mathrm{MPa}$ and $34.5 \mathrm{MPa}(23.3 \%$ decrease) after their immersion in distilled water for 7 and 30 days, respectively. A bigger decrease in compressive strength is observed, as anticipated, when specimens are immersed in $1 \mathrm{~mol} \mathrm{~L}^{-1} \mathrm{HCl}$. The recorded values are $27.5 \mathrm{MPa}$ and $12.5 \mathrm{MPa}(72.3 \%$ decrease), when the specimens are immersed for 7 and 30 days, respectively. It is also mentioned that a slight to moderate increase of solution $\mathrm{pH}$ is noted after immersion for 30 days. Immersion in distilled water results in an increase of $\mathrm{pH}$ from 7.6 to 10.8 , while immersion in $1 \mathrm{~mol} \mathrm{~L}^{-1}$ $\mathrm{HCl}$ results in a $\mathrm{pH}$ increase from 1.3 to 2.3 , as also shown in earlier studies with the use of AAMs produced from different precursors [36,40].

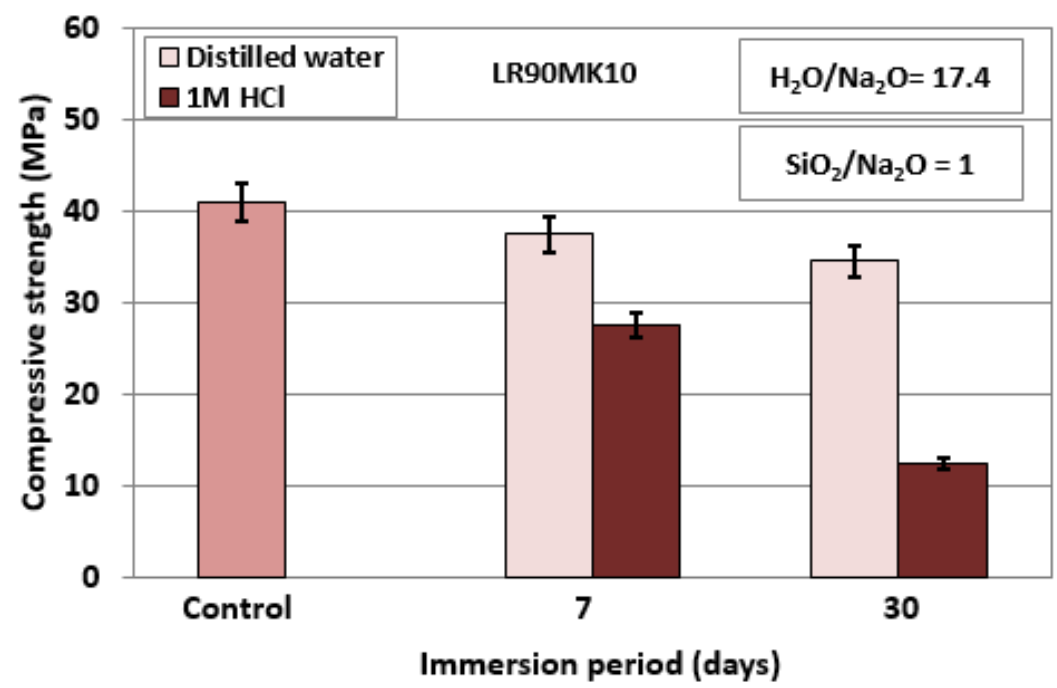

Figure 6. Compressive strength of LR90MK10 AAMs after immersion in distilled water and $1 \mathrm{~mol} \mathrm{~L}^{-1}$ $\mathrm{HCl}$ for 7 and 30 days; synthesis conditions: pre-curing time, $4 \mathrm{~h}$; curing period, $24 \mathrm{~h}$; curing temperature, $80^{\circ} \mathrm{C}$; ageing period, 7 days; error bars indicate the standard deviation of measurements obtained from three specimens.

\subsubsection{Comparison with Other Studies}

Table 6 compares the results of this study to those obtained from other studies that investigated the production of laterite soil-based AAMs using pre-cursors with different mineralogical composition that were not subjected to acid leaching that affects their nature.

Gualtieri et al. [76] produced AAMs by alkali activation of calcined laterite $\left(700{ }^{\circ} \mathrm{C}\right.$ for $2 \mathrm{~h}$ ) and metakaolin with the use of phosphoric acid, sodium hydroxide, and sodium silicate solutions as activators. The results showed that the highest compressive strength achieved was low, more specifically, $4 \mathrm{MPa}$, when the curing temperature was $60^{\circ} \mathrm{C}$ and the ageing period was 28 days. Phummipham et al. [77] produced AAMs by mixing marginal lateritic soil with fly ash at a mass ratio of 70:30, using sodium hydroxide and sodium silicate solutions as activators. The produced specimens acquired slightly higher compressive 
strength, $7.1 \mathrm{MPa}$, after curing at $30{ }^{\circ} \mathrm{C}$ and ageing for 7 days. Furthermore, Nkwaju et al. [78] investigated the potential of sugar cane bagasse as reinforcement of laterite soil-based geopolymer cement. The laterite soil, which was the precursor, was calcined at $700{ }^{\circ} \mathrm{C}$ for $4 \mathrm{~h}$ prior to use. The produced specimens acquired compressive strength that varied between 15 and $50 \mathrm{MPa}$, after curing at room temperature and ageing for 28 days. Lemougna et al. [67] produced AAMs using a mixture of calcined laterite $\left(700^{\circ} \mathrm{C}\right.$ for $\left.2 \mathrm{~h}\right)$ and ground granulated blast furnace slag ( $50 \mathrm{wt} \%$ by weight) as precursors, while the activators were sodium hydroxide and sodium silicate solutions. The paste cured at $25^{\circ} \mathrm{C}$ and, after ageing for 28 days, the produced specimens acquired a compressive strength of $65 \mathrm{MPa}$. This high value is due to the beneficial effect of slag, which is a by-product with noticeable alkali activation potential. Kaze et al. [73] produced AAMs using laterite calcined at $600{ }^{\circ} \mathrm{C}$ and meta-halloysite as precursors and sodium hydroxide and sodium silicate solutions as activators. Meta-halloysite was produced by calcining halloysite at $600{ }^{\circ} \mathrm{C}$ for $4 \mathrm{~h}$. The produced AMMs acquired a compressive strength of $45 \mathrm{MPa}$ after curing at $25 \pm 3{ }^{\circ} \mathrm{C}$ and ageing for 28 days. Finally, Obonyo et al. [79] investigated the geopolymerization potential of two lateritic soils, also after calcination at $700{ }^{\circ} \mathrm{C}$ for $4 \mathrm{~h}$ in the presence of river sand, also using sodium hydroxide and sodium silicate solutions as alkali activators. The paste was pressed and cured at room temperature for 7 days in order to produce disks of $40 \mathrm{~mm}$ diameter and 6-9 $\mathrm{mm}$ thickness. The authors studied in depth the mechanisms involved in the process as well as the mineralogy and morphology of the produced specimens.

Table 6. Comparison of results of various studies using laterite-based AAMs.

\begin{tabular}{|c|c|c|c|c|c|}
\hline \multirow[b]{2}{*}{ Raw Materials } & \multirow{2}{*}{$\begin{array}{c}\mathrm{Sio}_{2} / \mathrm{Na}_{2} \mathrm{O} \text { Molar } \\
\text { Ratio }\end{array}$} & \multicolumn{2}{|c|}{ Conditions } & \multirow{2}{*}{$\begin{array}{l}\text { Compressive Strength } \\
\text { (MPa) }\end{array}$} & \multirow[b]{2}{*}{ Reference } \\
\hline & & $\begin{array}{c}\text { Temperature } \\
\left({ }^{\circ} \mathrm{C}\right)\end{array}$ & $\begin{array}{l}\text { Ageing Period } \\
\text { (Days) }\end{array}$ & & \\
\hline $\begin{array}{l}\text { Laterite (calcined at } \\
700{ }^{\circ} \mathrm{C} \text { for } 2 \mathrm{~h} \text { ) and } \\
\text { metakaolin }\end{array}$ & 3.0 & 60 & 28 & 4 & [76] \\
\hline $\begin{array}{l}\text { Marginal lateritic soil } \\
\text { and fly ash }\end{array}$ & 5.6 & $27-30$ & 7 & 7.1 & [77] \\
\hline $\begin{array}{c}\text { Iron-rich laterite } \\
\text { (calcined at } 700{ }^{\circ} \mathrm{C} \text { for } \\
4 \mathrm{~h} \text { ) and bagasse fibers }\end{array}$ & 1.4 & 25 & 28 & $14-50$ & [78] \\
\hline $\begin{array}{c}\text { Laterite (calcined at } \\
700^{\circ} \mathrm{C} \text { for } 2 \mathrm{~h} \text { ) and slag }\end{array}$ & 1.6 & 25 & 28 & 65 & [67] \\
\hline $\begin{array}{c}\text { Laterite (calcined } \\
\text { at } 600^{\circ} \mathrm{C} \text { ) and } \\
\text { metahalloysite (calcined } \\
\text { halloysite clay at } 600{ }^{\circ} \mathrm{C} \text { ) }\end{array}$ & 0.75 & $25 \pm 3$ & 28 & 45 & [73] \\
\hline $\begin{array}{l}\text { Laterite leaching } \\
\text { residues and metakaolin }\end{array}$ & 1.0 & 80 & 7 & 45 & This study \\
\hline
\end{tabular}

In the present study, the produced AAMs, after alkali activation of laterite leaching residues amended with $10 \mathrm{wt} \%$ metakaolin, acquired a relatively high compressive strength of $41 \mathrm{MPa}$. The $\mathrm{SiO}_{2} / \mathrm{Na}_{2} \mathrm{O}$ molar ratios used varied from 0.3 to 1.6 due to the different configurations used. The results show that the use of metakaolin enables the successful alkali activation of a by-product that has very low inherent alkali activation potential.

\subsection{Mineralogy-Morphology of AAMs}

\subsubsection{XRD Analysis}

The XRD patterns of laterite leaching residues and selected AAMs are shown in Figure 7. It is observed that the main mineralogical phases present in the leaching residues 
are quartz $\left(\mathrm{SiO}_{2}\right)$ and hematite $\left(\mathrm{Fe}_{2} \mathrm{O}_{3}\right)$, while other minor phases are goethite $(\mathrm{FeO}(\mathrm{OH}))$, clinochlore $\left((\mathrm{Mg}, \mathrm{Fe})_{5} \mathrm{Al}\left(\mathrm{Si}_{3} \mathrm{Al}\right) \mathrm{O}_{10}(\mathrm{OH})_{8}\right)$, and lizardite $\left((\mathrm{Mg}, \mathrm{Fe})_{3} \mathrm{Si}_{2} \mathrm{O}_{5}(\mathrm{OH})_{4}\right)$ (Figure 7a). The main Ni-bearing phases detected in the leaching residues are chromite $\left(\mathrm{Cr}_{2} \mathrm{O}_{3} \mathrm{NiO}\right)$ and willemseite $\left((\mathrm{Ni}, \mathrm{Mg})_{3} \mathrm{Si}_{4} \mathrm{O}_{10}(\mathrm{OH})_{2}\right)$. As a result of the acid column leaching of limonitic laterite ( $\mathrm{CaO}$ content, $3.7 \mathrm{wt} \%$; Table 1 ) with the use $\mathrm{H}_{2} \mathrm{SO}_{4}$ solution, gypsum was also detected in the residues. On the other hand, the main mineralogical phases present in the XRD pattern of metakaolin are quartz and muscovite with a broad amorphous hump seen between $17^{\circ}$ and $40^{\circ}$ 2-Theta (Figure $7 \mathrm{~b}$ ).

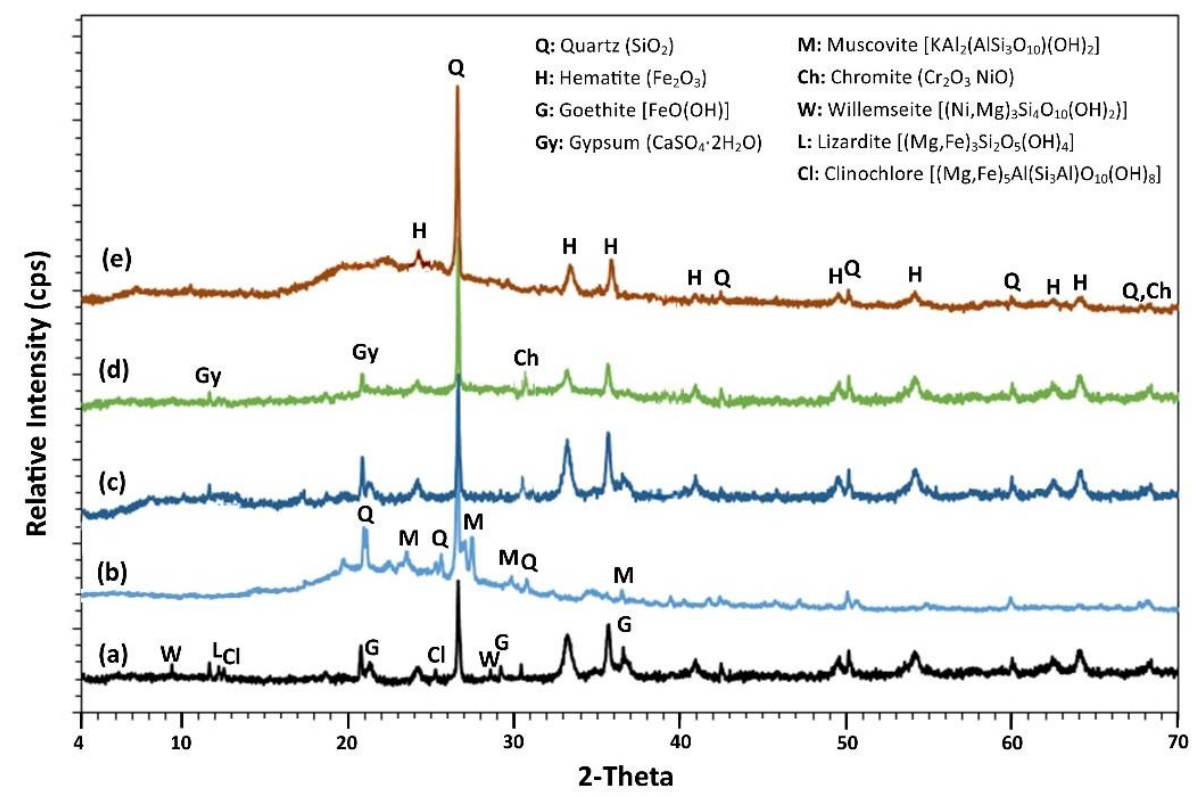

Figure 7. XRD patterns of (a) laterite leaching residues, (b) metakaolin, and (c) AAMs produced using only leaching residues (LR2 AAM) as well as by mixing (d) leaching residues and metakaolin at mass ratio 90:10 (LR90MK10) and (e) LR90MK10 after firing at $800{ }^{\circ} \mathrm{C}$ for $2 \mathrm{~h}$.

After alkali activation (LR2 AAM), which, as explained earlier in this paper, is poor due to the low content of $\mathrm{Al}_{2} \mathrm{O}_{3}$, a slight increase in the intensity of the peaks of the crystalline phases such as quartz and hematite is observed, compared to the ones present in the laterite leaching residues (Figure 7c). This observation confirms that these phases do not participate in the alkali activation reactions [67].

On the contrary, the intensity of the peaks of the crystalline phases present in LR90MK10 AAM is significantly lower compared to the ones present in the leaching residues; this is due to metakaolin addition, which has a high alkali activation potential as a result of the dissolution of sufficient number of Si and Al ions that participate in alkali activated reactions and the development of the geopolymeric network (Figure 7d). Thus, a broad hump between 17 and $40^{\circ}$ 2-Theta in the XRD pattern, which represents the amorphous content typical for metakaolin-based AAMs, is seen [80], which justifies the high compressive strength acquired by LR90MK10 AAM (45 MPa). After firing the leaching residues at $800{ }^{\circ} \mathrm{C}$, the amorphous hump of the LR90MK10 AAM is more apparent (Figure 7e). However, the center of the hump shifts towards lower 2-Theta, i.e., from $27^{\circ} 2-T_{h}$ ta to $26.5^{\circ}$ 2-Theta for the specimen before and after firing of the laterite leaching residues, respectively. This slight decrease implies partial depolymerization of metakaolin after firing at $800{ }^{\circ} \mathrm{C}$ and the subsequent reorganization of its structure resulting in partial reduction of compressive strength (23.1 MPa), as has also been reported in earlier studies [81]. In all laterite leaching residue based AAMs (before firing), minor but detectable quantities of crystalline chromite and gypsum were detected in the corresponding XRD patterns, indicating their partial dissolution after alkali activation. 


\subsubsection{FTIR Analysis}

The FTIR spectra, over the range $4000-400 \mathrm{~cm}^{-1}$, of the leaching residues and the AAMs produced by mixing them (unaltered or after firing) with metakaolin at mass ratio 90:10 (LR90MK10 AAM) are presented in Figure 8. In line with the XRD results, FTIR spectra of leaching residues show the characteristic bands at $460 \mathrm{~cm}^{-1}$ and $694 \mathrm{~cm}^{-1}$, the double bands at $778 \mathrm{~cm}^{-1}$ and $796 \mathrm{~cm}^{-1}$, and $1086 \mathrm{~cm}^{-1}$ and $1145 \mathrm{~cm}^{-1}$, which are attributed to quartz [82], and small shoulders at $528 \mathrm{~cm}^{-1}$ and $910 \mathrm{~cm}^{-1}$, which are attributed to hematite and goethite, respectively (Figure 8a) [24,49,67]. After alkali activation, the bands of the major crystalline phases (quartz and hematite) present in the laterite leaching residues remained almost unaffected in the LR2 AAM (Figure 8b), which confirms the low reactivity of the leaching residues during alkali-activation.

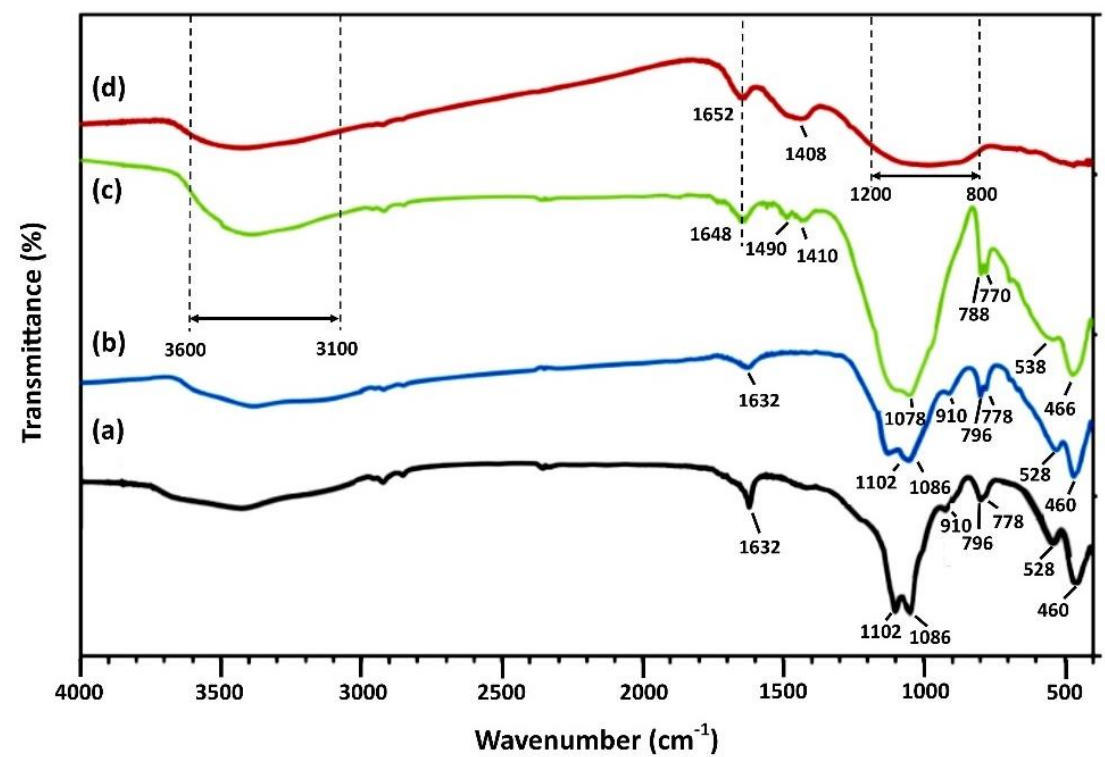

Figure 8. FTIR spectra of (a) laterite leaching residues and AAMs produced using (b) only leaching residues (LR2 AAM) as well as by mixing (c) leaching residues and metakaolin at mass ratio 90:10 (LR90MK10) and (d) LR90MK10 after firing at $800{ }^{\circ} \mathrm{C}$ for $2 \mathrm{~h}$.

However, compared to LR2 AAM, a clear difference in the shape, position, and depth of the bands can be seen in the spectrum of the LR90MK10 AAM in the region of $450-1250 \mathrm{~cm}^{-1}$ (Figure 8c). This is a result of the different vibrations belonging to the $\mathrm{Al}-, \mathrm{Fe}-$, and $\mathrm{Si}-$ containing phases in the raw material/binder (leaching residues and metakaolin) and the respective $\mathrm{Si}-\mathrm{O}-\mathrm{Si}, \mathrm{Fe}-\mathrm{O}-\mathrm{Si}$, and $\mathrm{Si}-\mathrm{O}-\mathrm{Al}$ bonds in the produced alkali activated matrices. In this context, the rocking band seen at $460 \mathrm{~cm}^{-1}$ in the leaching residues and the LR2 AAM (Figure 8a,b), which was slightly shifted to $466 \mathrm{~cm}^{-1}$ in LR90MK10 AAM (Figure 8c), is attributed to the bending motions of the Al- and Sicontaining phases [24,67]. The band present in LR2 AAM at $528 \mathrm{~cm}^{-1}$ was shifted to higher frequency, i.e., $538 \mathrm{~cm}^{-1}$, in LR90MK10 AAM, while the one observed at $910 \mathrm{~cm}^{-1}$ disappeared, possibly due to enhanced dissolution of Fe ions from the crystalline phase of hematite and goethite, respectively, that were present in the laterite leaching residues and their subsequent participation in the alkali-activated reactions $[73,83]$. Moreover, the major difference between LR2 and LR90MK10 AAMs is due to the shifting of the pair of strong bands at $778 \mathrm{~cm}^{-1}$ and $796 \mathrm{~cm}^{-1}$ observed in the LR2 (as well as in the leaching residues), which is associated with the asymmetric stretching vibrations of the $\mathrm{Si}-\mathrm{O}-\mathrm{Al}$ bonds towards lower wavenumbers $\left(770 \mathrm{~cm}^{-1}\right.$ and $\left.788 \mathrm{~cm}^{-1}\right)$, thus indicating the formation of inorganic gel in LR90MK10 AAM $[73,84]$. The displacement of the band shown at $1086 \mathrm{~cm}^{-1}$ in LR2 AAM to a lower wavelength $\left(1080 \mathrm{~cm}^{-1}\right)$ in LR90MK10 AAM indicates the dissolution of aluminosilicate phases present in the laterite leaching residues and their subsequent polymerization during alkali-activation. The intense absorption 
bands at $\sim 1410 \mathrm{~cm}^{-1}$ and $\sim 1490 \mathrm{~cm}^{-1}$, shown only in the LR90MK10 AAM, are attributed to asymmetric stretching vibrations of $\mathrm{O}-\mathrm{C}-\mathrm{O}$ bonds due to the formation of carbonation products from the reaction between the alkali activated silicates and the atmospheric $\mathrm{CO}_{2}$ during the curing period [73]. The weaker band located at $1632 \mathrm{~cm}^{-1}$ in the LR2 AAM, which shifted as a sharper peak at $1648 \mathrm{~cm}^{-1}$ in the LR90MK10 AAM, corresponds to the characteristic bending vibrations of $\mathrm{H}-\mathrm{O}-\mathrm{H}$ [85]. The presence of water is more evident in LR90MK10 AAM because a relatively wide absorption band region appeared between $3000 \mathrm{~cm}^{-1}$ and $3700 \mathrm{~cm}^{-1}$ belonging to stretching vibrations of the $\mathrm{OH}$ groups as a result of the hydration processes that took place during alkali activation. After firing the laterite leaching residues at $800^{\circ} \mathrm{C}$, a structural reorganization of the LR90MK10 AAM was noticed, which is indicated by the very broad band shown in the region of $800-1200 \mathrm{~cm}^{-1}$ as result of the stretching vibrations of the $\mathrm{Si}(\mathrm{Al})-\mathrm{O}$ groups (Figure 8d) [67]. This change in the polymeric matrix, along with the incomplete dihydroxylation, represented by a narrower band region between $3000 \mathrm{~cm}^{-1}$ and $3700 \mathrm{~cm}^{-1}$ compared to LR90MK10 AAM, results in lower compressive strength [86].

\subsubsection{SEM Analysis}

Figure 9 shows SEM-back-scattered electron (BSE) images of selected AAMs produced using only laterite leaching residues (LR2) as well as by mixing leaching residues and metakaolin at mass ratio 90:10 (LR90MK10) both as is and after firing at $800{ }^{\circ} \mathrm{C}$ for $2 \mathrm{~h}$. Among the AAMs examined, significant differences in the microstructure and the associated EDS analyses were noticed, depending on the nature of the starting raw materials/binders used. As also shown in the XRD analysis, the examination of LR2 AAM by SEM/EDS (Figure 9a) revealed a heterogeneous and porous structure with a poor cohesion between the paste and the raw material that is dominated by large quartz and hematite crystals $(>30 \mu \mathrm{m})$ with sharp edges, along with small tabular crystals $(<10 \mu \mathrm{m})$ of gypsum and some grains of goethite. It is important to note that some chromite particles with loose connections were also present inside the pore cavities of the inorganic matrix (dark areas) of the LR2 AAM. The large number of hollow cavities, irregular voids, and un-reacted or partially reacted particles indicate a low alkali activation degree, which is confirmed by the low compressive strength acquired by this specimen (1.3 MPa) [87].

On the other hand, as shown in Figure 9b,c, the microstructure of the AAMs produced by mixing laterite leaching residues and metakaolin at mass ratio 90:10 (LR90MK10) is mainly characterized by a more dense and homogeneous polymeric network when compared to LR2 AAM. Additionally, less voids and fewer unreactive particles, mainly round in shape, that exhibit better cohesion with the inorganic matrix of the LR90MK10 AAM as well as the presence of mixed aggregates, are shown (Figure 9b). As the alkaliactivation reactions progressed, gel products filled the hollow cavities and voids and strongly bonded the solid particles together with the precursors to form a compact matrix, with significantly reduced porosity and water absorption, as shown in Figure 9c (zoom of rectangular area of Figure $9 \mathrm{~b})$. SEM-EDS analyses confirmed the formation of $(\mathrm{N}, \mathrm{C})-\mathrm{A}-\mathrm{S}-\mathrm{H}$ gel with high ratios of $\mathrm{Al} / \mathrm{Si}$ and $\mathrm{Na} / \mathrm{Si}, 0.32$ and 0.43 , respectively, and $\mathrm{Ca} / \mathrm{Si}$ ratio of 0.15 . This microstructure justifies the higher compressive strength of the LR90MK10 AAM (41 MPa) among all specimens examined in this study (Table 4).

The microstructure of the LR90MK10 AAM was further evaluated using EDS elemental mapping analysis in order to elucidate the alkali activation mechanisms and the subsequent formation of reaction products in the polymeric matrix (Figure 10). The results of elemental mapping show a quite homogenous distribution of the main elements $\mathrm{Ca}, \mathrm{Fe}, \mathrm{Al}, \mathrm{Si}, \mathrm{S}$, and $\mathrm{Na}$ throughout the polymeric matrix, thus suggesting the formation of strong bonds due to reactions between leaching residues, metakaolin, and alkaline activators $(\mathrm{NaOH}$ and $\mathrm{Na}_{2} \mathrm{SiO}_{3}$ solutions). In this context, the elemental maps of $\mathrm{Al}, \mathrm{Ca}$, and $\mathrm{S}$ indicate that the high $\mathrm{Al}$ content of metakaolin ( $40.3 \%$ as oxide) as well as gypsum formed during the column acid leaching of the limonitic laterite with the use of $\mathrm{H}_{2} \mathrm{SO}_{4}$ were evenly distributed in the formed gel. The uniform distribution of gypsum inside the polymeric network indicates 
the synergistic interaction with the metakaolin added in the starting mixture, which results in the production of specimens with beneficial mechanical properties [88]. However, and in line with the XRD results, elemental mapping shows that some unreacted particles of quartz, hematite, and chromite are still present (bright spot areas) in the produced AAMs. It is important here to note that, despite the fact that laterite leaching residues have a relatively high content of $\mathrm{Cr}_{2} \mathrm{O}_{3}(2.5 \mathrm{wt} \%)$, as shown in Table 1, elemental distribution of $\mathrm{Cr}$ indicates that its dissolution from the raw material is extremely limited.
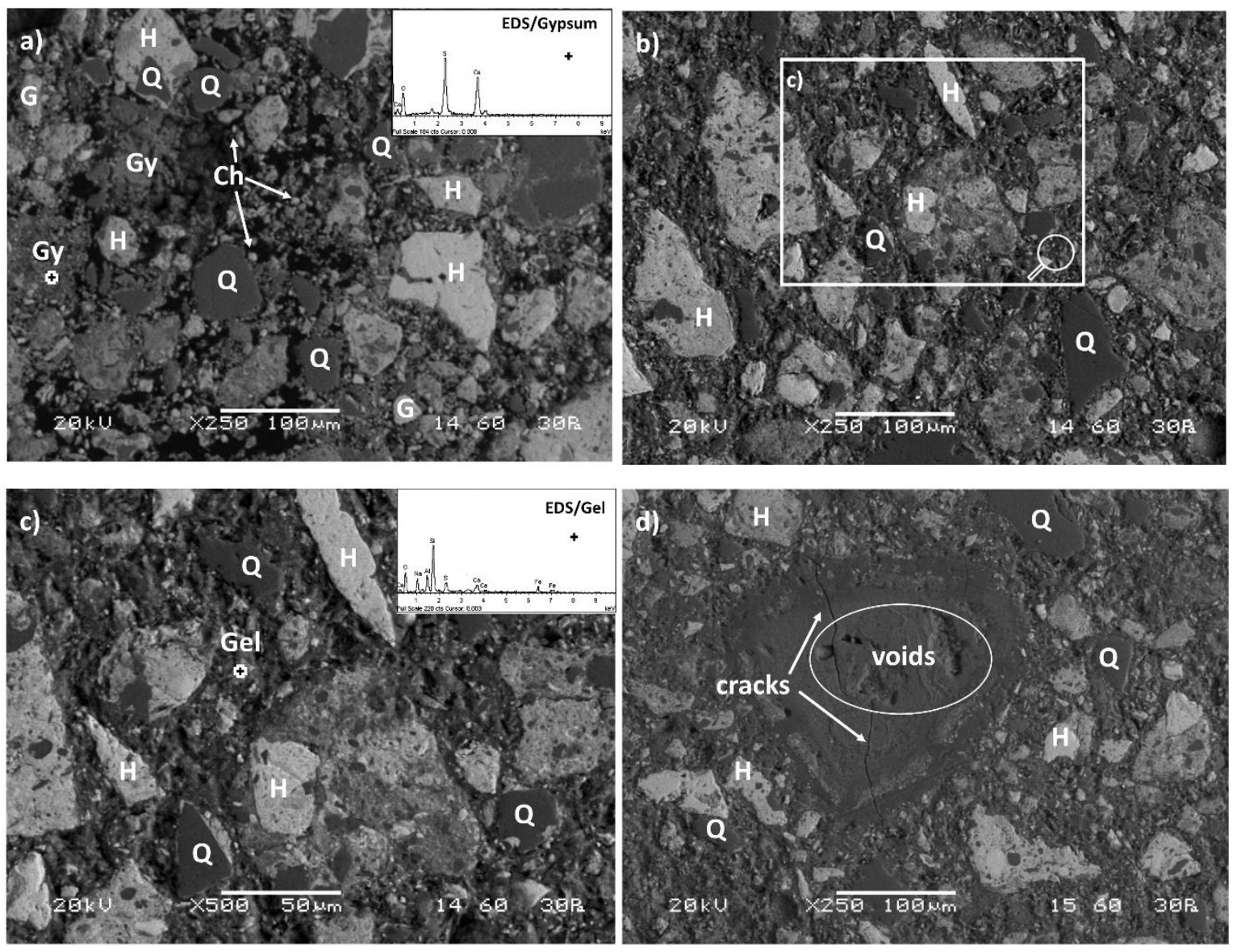

Figure 9. SEM-back-scattered electron (SEM-BSE) images of selected AAMs produced using (a) only laterite leaching residues (LR2 AAM) as well as by mixing $(\mathbf{b}, \mathbf{c})$ leaching residues and metakaolin at mass ratio 90:10 (LR90MK10) and (d) LR90MK10 fired at $800{ }^{\circ} \mathrm{C}$. Energy dispersive X-ray spectroscopy (EDS) spectra show in several spot locations the presence of crystalline phases, the formation of mixed aggregates, and newly formed products (Q: Quartz, H: Hematite, G: Goethite, Gy: Gypsum, Ch: Chromite, Gel: (N,C)-A-S-H gel ).

Regarding the produced LR90MK10 AAM after firing at $800{ }^{\circ} \mathrm{C}$ (Figure 9d), SEM analysis indicated the presence of a polymeric matrix filled with rounded particles, mostly hematite, seen in the center of the map. Even though firing at $800{ }^{\circ} \mathrm{C}$ resulted in a glassy structure, extensive cracking and noticeable formation of voids due to the evaporation of free water and shrinkage are visible in the fired specimen [89]. The co-existence of cracking and voids/shrinkage detected in the LR90MK10 AAM after firing is a major contributor to its $54 \%$ reduction in compressive strength (i.e., $23.1 \mathrm{MPa}$ ) compared to the LR90MK10 specimen. 

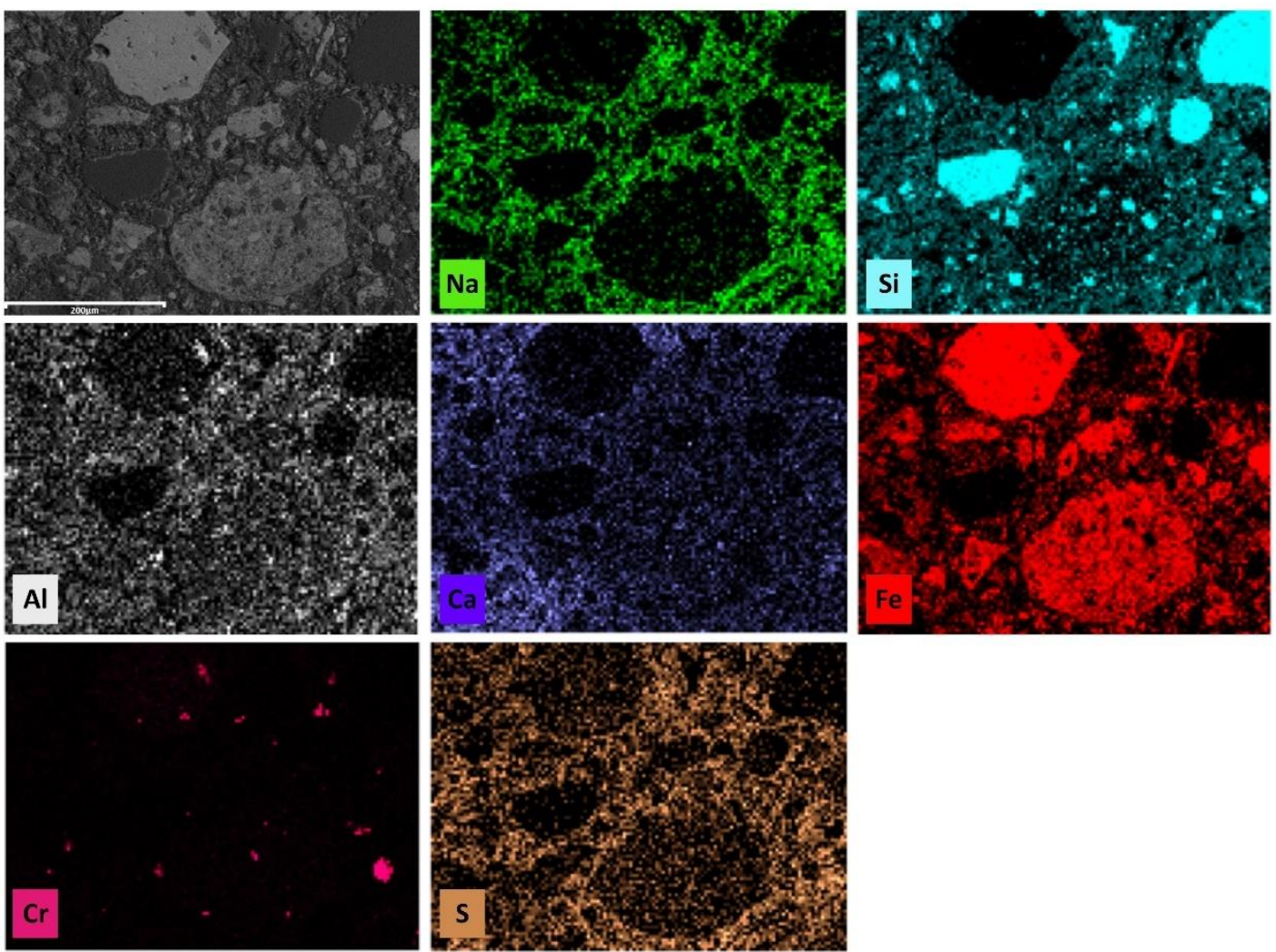

Figure 10. Elemental mapping analysis of LR90MK10 AAM produced by mixing laterite residues and metakaolin at mass ratio 90:10.

\section{Conclusions}

The present study is novel because it is the first one that explores the potential of, and investigates the main factors affecting, the alkali activation of laterite acid leaching residues. In order to accomplish this, the residues obtained after column leaching tests of Greek laterites were alkali activated without alteration, after calcination at 800 and $1000{ }^{\circ} \mathrm{C}$, or after the addition of metakaolin at mass ratios leaching residues: metakaolin 95:5 and 90:10, in order to increase the reactivity of the starting mixture.

The experimental results show that the unaltered leaching residues cannot be practically alkali activated and the compressive strength of the produced AAMs hardly reaches 1.4 MPa, while the addition of $10 \mathrm{wt} \%$ metakaolin in the starting mixture results in the production of AAMs with noticeably higher compressive strength $(41 \mathrm{MPa})$. The use of metakaolin is considered beneficial during alkali activation due to its high amorphous content and its pozzolanic nature, provided that the calcination of kaolin takes place at the most suitable temperature (around $750^{\circ} \mathrm{C}$ ). On the other hand, calcination of the residues at 800 and $1000{ }^{\circ} \mathrm{C}$ has little or no beneficial effect on alkali activation. The produced AAMs under the optimum synthesis conditions (using molar ratios $\mathrm{H}_{2} \mathrm{O} / \mathrm{Na}_{2} \mathrm{O}, 17.4$ and $\mathrm{SiO}_{2} / \mathrm{Na}_{2} \mathrm{O}, 1.0$ in the alkali activation solution consisting of $\mathrm{NaOH}$ and $\mathrm{Na}_{2} \mathrm{SiO}_{3}$ solutions; pre-curing time, $4 \mathrm{~h}$; curing temperature, $80^{\circ} \mathrm{C}$; curing time, $24 \mathrm{~h}$; ageing period, 7 days) also exhibited good structural integrity when subjected to high temperature firing for $2 \mathrm{~h}$ and after immersion in distilled water or acidic solution $\left(1 \mathrm{~mol} \mathrm{~L}^{-1} \mathrm{HCl}\right)$ for 7 and 30 days.

The use of analytical techniques, including XRD, FTIR, and SEM-EDS, provided useful insights on the beneficial effect of metakaolin addition towards the improvement of the alkali activation potential of laterite acid leaching residues.

The results of this study can be used for the development of an integrated approach, which involves leaching residue valorization for the production of much higher added value products that can be used as binders or construction elements, in line with the zero-waste approach and circular economy principles. 
Author Contributions: K.K. conceived the idea, designed the experiments, and reviewed the paper. G.B. carried out all mineralogical analyses, analyzed data, and wrote the paper. V.K. and E.P. carried out the experiments and wrote the first draft of the paper. All authors have read and agreed to the published version of the manuscript.

Funding: This work was supported by the European Union's Horizon 2020 research and innovation program: Metal Recovery from Low-Grade Ores and Wastes Plus (METGROW+) (grant number 690088). Project website: https:/ / metgrowplus.eu.

Institutional Review Board Statement: Not applicable.

Informed Consent Statement: Not applicable.

Data Availability Statement: The data presented in this study are available on request from the corresponding author. The data are not publicly available yet, due to the fact that they are also part of an ongoing PhD study.

Acknowledgments: The authors wish to express their sincere thanks to the three anonymous reviewers for their constructive comments, which improved the quality of the paper.

Conflicts of Interest: The authors declare no conflict of interest.

\section{References}

1. Oraby, E.A.; Eksteen, J.J.; Karrech, A.; Attar, M. Gold extraction from paleochannel ores using an aerated alkaline glycine lixiviant for consideration in heap and in-situ leaching applications. Miner. Eng. 2019, 138, 112-118. [CrossRef]

2. Petersen, J. Heap leaching as a key technology for recovery of values from low-grade ores-A brief overview. Hydrometallurgy 2016, 165, 206-212. [CrossRef]

3. Thenepalli, T.; Chilakala, R.; Habte, L.; Tuan, L.Q.; Kim, C.S. A Brief Note on the Heap Leaching Technologies for the Recovery of Valuable Metals. Sustainability 2019, 11, 3347. [CrossRef]

4. Spooren, J.; Breemersch, K.; Dams, Y.; Mäkinen, J.; Lopez, M.; González-Moya, M.; Tripiana, M.; Pontikes, Y.; Kurylak, W.; Pietek, G.; et al. Near-zero-waste processing of low-grade, complex primary and secondary ores: Challenges and opportunities. Resour. Conserv. Recy. 2020, 160, 104919. [CrossRef]

5. Arpalahti, A.; Lundström, M. The leaching behavior of minerals from a pyrrhotite-rich pentlandite ore during heap leaching. Miner. Eng. 2018, 119, 116-125. [CrossRef]

6. Komnitsas, C.; Pooley, F.D. Mineralogical characteristics and treatment of refractory gold ores. Miner. Eng. 1989, 2, 449-457. [CrossRef]

7. Oxley, A.; Smith, M.E.; Caceres, O. Why heap leach nickel laterites? Miner. Eng. 2016, 88, 53-60. [CrossRef]

8. Ram, R.; Beiza, L.; Becker, M.; Pownceby, M.I.; Chen, M.; Yang, Y.; Yang, S.; Petersen, J. Study of the leaching and pore evolution in large particles of a sulfide ore. Hydrometallurgy 2020, 192, 105261. [CrossRef]

9. Ulrich, B.; Andrade, H.; Gardner, T. Lessons learnt from heap leaching operations in South America-An update. J. S. Afr. Inst. Min. Metall. 2003, 103, 23-28.

10. Catalan, L.J.J.; Li, M.G. Decommissioning of copper heap-leach residues by rinsing with water and alkaline solutions-A pilot scale study. Environ. Eng. Sci. 2000, 17, 191-202. [CrossRef]

11. Gaulier, C.; Billon, G.; Lesven, L.; Falantin, C.; Superville, P.J.; Baeyens, W.; Gao, Y. Leaching of two northern France slag heaps: Influence on the surrounding aquatic environment. Environ. Pollut. 2020, 257, 113601. [CrossRef] [PubMed]

12. Lupo, J.F. Sustainable issues related to heap leaching operations. J. S. Afr. Inst. Min. Metall. 2012, 112, 1021-1030.

13. McDonald, G.R.; Li, J.; Austin, P.J. High temperature pressure oxidation of a low-grade nickel sulfide concentrate with control of the residue composition. Minerals 2020, 10, 249. [CrossRef]

14. Zevgolis, E.; Zografidis, C.; Halikia, I. The reducibility of the Greek nickeliferous laterites: A review. Miner. Process. Ext. Metall. 2010, 119, 9-17. [CrossRef]

15. Petrakis, E.; Karmali, V.; Komnitsas, K. Factors affecting nickel upgrade during selective grinding of low-grade limonitic laterites. Miner. Process. Ext. Metall. 2018, 1-10. [CrossRef]

16. Putzolu, F.; Balassone, G.; Boni, M.; Maczurad, M.; Mondillo, N.; Najorka, J.; Pirajno, F. Mineralogical association and Ni-Co deportment in the Wingellina oxide-type laterite deposit (Western Australia). Ore Geol. Rev. 2018, 97, 21-34. [CrossRef]

17. Komnitsas, K.; Petrakis, E.; Pantelaki, O.; Kritikaki, A. Column leaching of saprolitic laterites with sulphuric acid. In Proceedings of the 10th European Metallurgical Conference, EMC 2019, Dusseldorf, Germany, 23-26 June 2019; Volume 1, pp. $273-284$.

18. Bartzas, G.; Komnitsas, K. Life cycle assessment of ferronickel production in Greece. Resour. Conserv. Recy. 2015, 105, 113-122. [CrossRef]

19. Panagiotopoulos, N.; Agatzini, S.; Kontopoulos, A. Extraction of nickel and cobalt from serpentinic type laterites by atmospheric pressure sulfuric acid leaching. In Proceedings of the 115th TMS-AIME Annual Meeting, New Orleans, LA, USA, 2-6 March 1986; p. A86-30. 
20. Mystrioti, C.; Papassiopi, N.; Xenidis, A.; Komnitsas, K. Counter-Current Leaching of Low-Grade Laterites with Hydrochloric Acid and Proposed Purification Options of Pregnant Solution. Minerals 2018, 8, 599. [CrossRef]

21. Kontopoulos, A.; Komnitsas, K. Sulphuric acid pressure leaching of low-grade Greek laterites. In Proceedings of the 1st International Symposium on Hydrometallurgy, Beijing, China, 12-15 October 1988; Zheng, Y., Xu, J., Eds.; Pergamon Press: Oxford, UK, 1988; pp. 140-144.

22. Agatzini-Leonardou, S.; Zafiratos, J.G.; Spathis, D. Beneficiation of a Greek serpentinic nickeliferous ore: Part I. Mineral processing. Hydrometallurgy 2004, 74, 259-265. [CrossRef]

23. Agatzini-leonardou, S.; Tsakiridis, P.E.; Oustadakis, P.; Karidakis, T.; Katsiapi, A. Hydrometallurgical process for the separation and recovery of nickel from sulphate heap leach liquor of nickeliferrous laterite ores. Miner. Eng. 2009, 22, 1181-1192. [CrossRef]

24. Komnitsas, K.; Petrakis, E.; Pantelaki, O.; Kritikaki, A. Column leaching of Greek low-grade limonitic laterites. Minerals 2018, 8, 377. [CrossRef]

25. Davidovits, J. Geopolymers-Inorganic polymeric new materials. J. Therm. Anal. Calorim. 1991, 37, 1633-1656. [CrossRef]

26. Duxson, P.; Lukey, G.C.; van Deventer, J.S.J. Thermal evolution of metakaolin geopolymers: Part 1-Physical evolution. J. Non Cryst. Solids 2006, 352, 5541-5555. [CrossRef]

27. Khale, D.; Chaudhary, R. Mechanism of geopolymerization and factors influencing its development: A review. J. Mater. Sci. 2007, 42, 729-746. [CrossRef]

28. Palomo, A.; Grutzeck, M.W.; Blanco, M.T. Alkali-Activated fly ashes, a cement for the future. Cem. Concr. Res. 1999, 29, 1323-1329. [CrossRef]

29. Komnitsas, K.; Zaharaki, D. Geopolymerisation. A review and prospects for the minerals industry. Miner. Eng. 2007, 20, 1261-1277. [CrossRef]

30. Zaharaki, D.; Komnitsas, K.; Perdikatsis, V. Use of analytical techniques for identification of inorganic polymer gel composition. J. Mater. Sci. 2010, 45, 2715-2724. [CrossRef]

31. Duxson, P.; Fernández-Jiménez, A.; Provis, J.L.; Lukey, G.C.; Palomo, A.; Van Deventer, J.S.J. Geopolymer technology: The current state of the art. J. Mater. Sci. 2007, 42, 2917-2933. [CrossRef]

32. Bernal, S.A.; de Gutierrez, R.M.; Provis, J.L.; Rose, V. Effect of silicate modulus and metakaolin incorporation on the carbonation of alkali silicate-activated slags. Cem. Concr. Res. 2010, 40, 898-907. [CrossRef]

33. Lemougna, P.N.; Wang, K.-T.; Tang, Q.; Melo, U.C.; Cui, X.-M. Recent developments on inorganic polymers synthesis and applications. Ceram. Int. 2016, 42, 15142-15159. [CrossRef]

34. Peys, A.; Douvalis, A.P.; Hallet, V.; Rahier, H.; Blanpain, B.; Pontikes, Y. Inorganic polymers from $\mathrm{CaO}-\mathrm{FeOx}-\mathrm{SiO} 2 \mathrm{Slag}$ : The start of oxidation of Fe and the formation of a mixed valence binder. Front. Mater. Sci. 2019, 6, 212. [CrossRef]

35. Yip, C.K.; Lukey, G.C.; van Deventer, J.S.J. The coexistence of geopolymeric gel and calcium silicate hydrate at the early stage of alkaline activation. Cem. Concr. Res. 2005, 35, 1688-1697. [CrossRef]

36. Komnitsas, K.; Bartzas, G.; Karmali, V.; Petrakis, E.; Kurylak, W.; Pietek, G.; Kanasiewics, J. Assessment of alkali activation potential of a Polish ferronickel slag. Sustainability 2019, 11, 1863. [CrossRef]

37. Azevedo, A.G.D.S.; Strecker, K. Brazilian fly ash based inorganic polymers production using different alkali activator solutions. Ceram. Int. 2017, 43, 9012-9018. [CrossRef]

38. Hounsi, A.D.; Gisèle, L.-N.; Djétéli, G.; Blanchart, P. Kaolin-based geopolymers: Effect of mechanical activation and curing process. Constr. Build. Mater. 2013, 42, 105-113. [CrossRef]

39. Rovnaník, P. Effect of curing temperature on the development of hard structure of metakaolin-based geopolymer. Constr. Build. Mater. 2010, 24, 1176-1183. [CrossRef]

40. Soultana, A.; Valouma, A.; Bartzas, G.; Komnitsas, K. Properties of Inorganic Polymers Produced from Brick Waste and Metallurgical Slag. Minerals 2019, 9, 551. [CrossRef]

41. Alshaaer, M. Synthesis and characterization of self-healing geopolymer composite. Constr. Build. Mater. 2020, $245,118432$. [CrossRef]

42. Hertel, T.; Pontikes, Y. Geopolymers, inorganic polymers, alkali-activated materials and hybrid binders from bauxite residue (red mud)-Putting things in perspective. J. Clean. Prod. 2020, 258, 120610. [CrossRef]

43. Komnitsas, K.; Zaharaki, D.; Vlachou, A.; Bartzas, G.; Galetakis, M. Effect of synthesis parameters on the quality of construction and demolition wastes (CDW) geopolymers. Adv. Powder Technol. 2015, 26, 368-376. [CrossRef]

44. Palankar, N.; Ravi Shankar, A.U.; Mithun, B.M. Studies on eco-friendly concrete incorporating industrial waste as aggregates. Int. J. Sustain. Built Environ. 2015, 4, 378-390. [CrossRef]

45. Peys, A.; Douvalis, A.P.; Siakati, C.; Rahier, H.; Blanpain, B.; Pontikes, Y. The influence of air and temperature on the reaction mechanism and molecular structure of Fe-silicate inorganic polymers. J. Non Cryst. Solids 2019, 526, 119675. [CrossRef]

46. Provis, J.L.; Bernal, S.A. Geopolymers and related alkali-activated materials. Annu. Rev. Mater. Res. 2014, 44, 229-327. [CrossRef]

47. Lemougna, P.N.; MacKenzie, K.J.D.; Melo, U.F.C. Synthesis and thermal properties of inorganic polymers (geopolymers) for structural and refractory applications from volcanic ash. Ceram. Int. 2011, 37, 3011-3018. [CrossRef]

48. Oyelami, C.A.; Van Rooy, J.L. A review of the use of lateritic soils in the construction/development of sustainable housing in Africa: A geological perspective. J. Afr. Earth Sci. 2016, 119, 226-237. [CrossRef]

49. Komnitsas, K.; Petrakis, E.; Bartzas, G.; Karmali, V. Column leaching of low-grade saprolitic laterites and valorization of leaching residues. Sci. Total Environ. 2019, 665, 347-357. [CrossRef] 
50. Konan, K.L.; Peyratout, C.; Smith, A.; Bonnet, J.-P.; Rossignol, S.; Oyetola, S. Comparison of surface properties between kaolin and metakaolin in concentrated lime solutions. J. Colloid Interface Sci. 2009, 339, 103-109. [CrossRef]

51. Kakali, G.; Perrraki, T.; Tsivilis, S.; Badogiannis, E. Thermal Treatment of Kaolin: The Effect of Mineralogy on the Pozzolanic Activity. Appl. Clay Sci. 2001, 20, 73-80. [CrossRef]

52. Shvarzman, A.; Kovler, K.; Grader, G.S.; Shter, G.E. The effect of dehydroxylation/amorphization degree on pozzolanic activity of kaolinite. Cem. Concr. Res. 2003, 33, 405-416. [CrossRef]

53. British Standards Institute. BS EN 1936: Natural Stone Test Methods. Determination of Real Density and Apparent Density and of Total and Open Porosity; NP EN 1936:2006; BSI: London, UK, 2007.

54. Ascensão, G.; Marchi, M.; Segata, M.; Faleschini, F.; Pontikes, Y. Reaction kinetics and structural analysis of alkali activated Fe-Si-Ca rich materials. J. Clean. Prod. 2020, 246, 119065. [CrossRef]

55. Aughenbaugh, K.L.; Williamson, T.; Juenger, M.C.G. Critical evaluation of strength prediction methods for alkali-activated fly ash. Mater. Struct. 2015, 48, 607-620. [CrossRef]

56. Bumanis, G.; Vitola, L.; Bajare, D.; Dembovska, L.; Pundiene, I. Impact of reactive $\mathrm{SiO}_{2} / \mathrm{Al}_{2} \mathrm{O}_{3}$ ratio in precursor on durability of porous alkali activated materials. Ceram. Int. 2017, 43, 5471-5477. [CrossRef]

57. He, P.; Wang, M.; Fu, A.; Jia, D.; Yan, S.; Yuan, J.; Xu, J.; Wang, P.; Zhou, Y. Effects of Si / Al ratio on the structure and properties of metakaolin based geopolymer. Ceram. Int. 2016, 42, 14416-14422. [CrossRef]

58. Lahoti, M.; Wong, K.K.; Yang, E.-H.; Tan, K.H. Effects of Si/Al molar ratio on strength endurance and volume stability of metakaolin geopolymers subject to elevated temperature. Ceram. Int. 2018, 44, 5726-5734. [CrossRef]

59. Sun, J.; Zhang, Z.; Zhuang, S.; He, W. Hydration properties and microstructure characteristics of alkali-activated steel slag. Constr. Build. Mater. 2020, 241, 118141. [CrossRef]

60. Tennakoon, C.; De Silva, P.; Sagoe-Crentsil, K.; Sanjayan, J.G. Influence and role of feedstock Si and Al content in Geopolymer synthesis. J. Sust. Cem Based Mater. 2014, 4, 129-139. [CrossRef]

61. Wang, Y.; Liu, X.; Zhang, W.; Li, Z.; Zhang, Y.; Li, Y.; Ren, Y. Effects of Si / Al ratio on the efflorescence and properties of fly ash based geopolymer. J. Clean. Prod. 2020, 244, 11852. [CrossRef]

62. Wang, R.; Wang, J.; Dong, T.; Ouyang, G. Structural and mechanical properties of geopolymers made of aluminosilicate powder with different $\mathrm{SiO}_{2} / \mathrm{Al}_{2} \mathrm{O}_{3}$ ratio: Molecular dynamics simulation and microstructural experimental study. Constr. Build. Mater. 2020, 240, 117935. [CrossRef]

63. Zhang, Q.; Ji, T.; Yang, Z.; Wang, C.; Wu, H.-C. Influence of different activators on microstructure and strength of alkali-activated nickel slag cementitious materials. Constr. Build. Mater. 2020, 235, 117449. [CrossRef]

64. Kpinsoton, G.M.R.; Karoui, H.; Richardson, Y.; Koffi, B.N.D.S.; Yacouba, H.; Motuzas, J.; Drobek, M.; Lawane Gana, A. New insight into the microstructure of natural calcined laterites and their performance as heterogeneous Fenton catalyst for methylene blue degradation. Reac. Kinet. Mech. Cat. 2018, 124, 931-956. [CrossRef]

65. Mascarin, L. Characterization and Thermodynamic Modelling of Alkali-Activated Calcined Clays: Potentiality of Cameroon's Laterites as Eco-Sustainable Binders. Master's Thesis, Department of Geosciences, University of Padua, Padova, Italy, 19 July 2018.

66. Komnitsas, K.; Zaharaki, D.; Perdikatsis, V. Effect of synthesis parameters on the compressive strength of low-calcium ferronickel slag inorganic polymers. J. Hazard. Mater. 2009, 161, 760-768. [CrossRef] [PubMed]

67. Lemougna, P.N.; Wang, K.-T.; Tang, Q.; Kamseu, E.; Billong, N.; Melo, U.C.; Cui, X.-M. Effect of slag and calcium carbonate addition on the development of geopolymer from indurated laterite. Appl. Clay Sci. 2017, 148, 109-117. [CrossRef]

68. Vogt, O.; Ukrainczyk, N.; Ballschmiede, C.; Koenders, E. Reactivity and microstructure of metakaolin based geopolymers: Effect of fly ash and liquid/solid contents. Materials (Basel) 2019, 12, 3485. [CrossRef] [PubMed]

69. Yuan, J.; He, P.; Jia, D.; Yang, C.; Zhang, Y.; Yan, S.; Yang, Z.; Duan, X.; Wang, S.; Zhou, Y. Effect of curing temperature and $\mathrm{SiO}_{2} / \mathrm{K}_{2} \mathrm{O}$ molar ratio on the performance of metakaolin-based geopolymers. Ceram. Int. 2016, 42, 16184-16190. [CrossRef]

70. Jackson, P.R.; Radford, D.W. Effect of initial cure time on toughness of geopolymer matrix composites. Ceram. Int. 2017, 43, 9884-9890. [CrossRef]

71. Lemougna, P.N.; Chinje Melo, U.F.; Delplancke, M.-P.; Rahier, H. Influence of the activating solution composition on the stability and thermo-mechanical properties of inorganic polymers (geopolymers) from volcanic ash. Constr. Build. Mater. 2013, 48, 278-286. [CrossRef]

72. Zhang, M.; Zhao, M.; Zhang, G.; Sietins, J.M.; Granados-Focil, S.; Pepi, M.S.; Yan Xu, Y.; Tao, M. Reaction kinetics of red mud-fly ash based geopolymers: Effects of curing temperature on chemical bonding, porosity, and mechanical strength. Cem. Concr. Comp. 2018, 93, 175-185. [CrossRef]

73. Kaze, C.R.; Venyite, P.; Nana, A.; Juvenal, D.N.; Tchakoute, H.K.; Rahier, H.; Kamseu, E.; Melo, U.C.; Leonelli, C. Meta-halloysite to improve compactness in iron-rich laterite-based alkali activated materials. Mater. Chem. Phys. 2020, 239, 122268. [CrossRef]

74. Heap, M.J.; Lavallée, Y.; Laumann, A.; Hess, K.-U.; Meredith, P.G.; Dingwell, D.B.; Huismann, S.; Weise, F. The influence of thermal-stressing (up to $1000{ }^{\circ} \mathrm{C}$ ) on the physical, mechanical, and chemical properties of siliceous-aggregate, high-strength concrete. Constr. Build. Mater. 2013, 42, 248-265. [CrossRef]

75. Duxson, P.; Provis, J.L.; Lukey, G.C.; van Deventer, J.S.J. The role of inorganic polymer technology in the development of 'green concrete'. Cem. Concr. Res. 2007, 37, 1590-1597. [CrossRef] 
76. Gualtieri, M.L.; Romagnoli, M.; Pollastri, S.; Gualtieri, A.F. Inorganic polymers from laterite using activation with phosphoric acid and alkaline sodium silicate solution: Mechanical and microstructural properties. Cem. Concr. Res. 2015, 67, 259-270. [CrossRef]

77. Phummiphan, I.; Horpibulsuk, S.; Sukmak, P.; Chinkulkijniwat, A.; Arulrajah, A.; Shen, S.-L. Stabilisation of marginal lateritic soil using high calcium fly ash-based geopolymer. Road Mater. Pavement Des. 2016, 17, 877-891. [CrossRef]

78. Nkwaju, R.Y.; Djobo, J.N.Y.; Nouping, J.N.F.; Huisken, P.W.M.; Deutou, J.G.N.; Courard, L. Iron-rich laterite-bagasse fibers based geopolymer composite: Mechanical, durability and insulating properties. Appl. Clay Sci. 2019, 183, 105333. [CrossRef]

79. Obonyo, E.A.; Kamseu, E.; Lemougna, P.N.; Tchamba, A.B.; Melo, U.C.; Leonelli, C.A. Sustainable approach for the geopolymerization of natural iron-rich aluminosilicate. Sustainability 2014, 6, 5535-5553. [CrossRef]

80. Yi, C.; Boluk, Y.; Bindiganavile, V. Enhancing alkali-activation of metakaolin-based geopolymers using dry water. J. Clean. Prod. 2020, 258, 120676. [CrossRef]

81. Tchakouté, H.K.; Rüscher, C.H.; Kong, S.; Kamseu, E.; Leonelli, C. Comparison of metakaolin-based geopolymer cements from commercial sodium waterglass and sodium waterglass from rice husk ash. J. Sol Gel Sci. Technol. 2016, 78, 492-506. [CrossRef]

82. Criado, M.; Aperador, W.; Sobrados, I. Microstructural and Mechanical Properties of Alkali Activated Colombian Raw Materials. Materials 2016, 9, 158. [CrossRef]

83. Kaze, C.R.; Djobo, J.N.Y.; Nana, A.; Tchakoute, H.K.; Kamseu, E.; Melo, U.C.; Leonelli, C.; Rahier, H. Effect of silicate modulus on the setting, mechanical strength and microstructure of iron-rich aluminosilicate (laterite) based-geopolymer cured at room temperature. Ceram. Int. 2018, 44, 21442-21450. [CrossRef]

84. Kaze, C.R.; Tchakoute, H.K.; Mbakop, T.T.; Mache, J.R.; Kamseu, E.; Melo, U.C.; Leonelli, C. Synthesis and properties of inorganic polymers (geopolymers) derived from Cameroon-meta-halloysite. Ceram. Int. 2018, 44, 18499-18508. [CrossRef]

85. Ricciotti, L.; Molino, A.J.; Roviello, V.; Chianese, E.; Cennamo, P.; Roviello, G. Geopolymer Composites for Potential Applications in Cultural Heritage. Environments 2017, 4, 91. [CrossRef]

86. Adesanya, E.; Ohenoja, K.; Yliniemi, J.; Illikainen, M. Mechanical trans-formation of phyllite mineralogy toward its use as alkali-activated binderprecursor. Miner. Eng. 2020, 145, 106093. [CrossRef]

87. Song, W.; Zhu, Z.; Pu, S.; Wan, Y.; Huo, W.; Song, S.; Zhang, J.; Yao, K.; Hu, L. Efficient use of steel slag in alkali-activated fly ash-steel slag-ground granulated blast furnace slag ternary blends. Constr. Build. Mater. 2020, 259, 119814. [CrossRef]

88. Vimmrová, A.; Keppert, M.; Michalko, O.; Černý, R. Calcined gypsum-lime-metakaolin binders: Design of optimal composition. Cem. Concr. Comp. 2014, 52, 91-96. [CrossRef]

89. Rickard, W.D.A.; Gluth, G.J.G.; Pistol, K. In-situ thermo-mechanical testing of fly ash geopolymer concretes made with quartz and expanded clay aggregates. Cem. Concr. Res. 2016, 80, 33-43. [CrossRef] 